\title{
Regulations Concerning Agriculture and Air Pollution
}

\author{
Chiara Bertora*, Francesco Alluvione, Laura Zavattaro, Carlo Grignani \\ Dipartimento di Agronomia, Selvicoltura e Gestione del Territorio, Università di Torino \\ Via Leonardo da Vinci 44, 10095 Grugliasco, Italy
}

Received: 29 September 2009. Accepted: 12 January 2010.

\begin{abstract}
The main issues related to the atmospheric pollution are the stratospheric ozone depletion, the transboundary air pollution, the troposphere air quality and the climate change. The three last decades have seen the birth of several measures for the atmosphere safeguard. Agricultural activities play a key role in determining, preventing and mitigating atmospheric pollution.

The emission to atmosphere of different ozone-depleting substances is regulated by the Montreal Protocol. The role of agriculture activity in ozone depletion is linked to the utilization of methyl bromide as soil sterilant and to the emission of nitrogen oxides and nitrous oxide, from agricultural soils.

The Convention on long-range transboundary air pollution regulates the emission of several pollutants, i.e. sulphur dioxide, nitrogen oxides, ammonia, non methane volatile organic compounds, carbon monoxide, heavy metals, persistent organic pollutants, and tropospheric ozone. The agriculture sector is responsible for a large part of the emissions of ammonia and nitrogen oxides, mainly through manure management and nitrogen fertilization, and of most persistent organic pollutants, largely used in the past as insecticides and fungicides.

The increase of the greenhouse gases (GHGs) concentration in the atmosphere is under the control of the Kyoto Protocol. Agriculture accounts for $59-63 \%$ of global non- $\mathrm{CO}_{2}$ GHGs emissions but at the same time it contributes to the atmospheric $\mathrm{CO}_{2}$ concentration stabilisation through the substitution of fossil fuels by biofuels and the sequestration of $\mathrm{C}$ in soil and vegetal biomass.

In this paper we provide an outline of the numerous scientific and legislative initiatives aimed at protecting the atmosphere, and we analyse in detail the agriculture sector in order to highlight both its contribution to atmospheric pollution and the actions aimed at preventing and mitigating it.
\end{abstract}

Key-words: stratospheric ozone depletion, transboundary air pollution, climate change, greenhouse gases, agriculture activity, regulations.

\section{Introduction}

Air pollution was defined as "the introduction by man, directly or indirectly, of substances or energy into the air resulting in deleterious effects of such a nature as to endanger human health, harm living resources and ecosystems and material property and impair or interfere with amenities and other legitimate uses of the environment" (CLRTAP, 1979).

Human activities are responsible of the emission to the atmosphere of several pollutant substances, that interact with environmental resources and human health at different levels and therefore are object of numerous regulations.
The earliest activity of mankind contributing to the air pollution is agriculture, that since ancient times has been altering the composition of the atmosphere. However agriculture is one of the few activities that can play the positive role of reducing the impact of other emissions, recycling or fixing some gases.

Under the coordination of the United $\mathrm{Na}$ tions Environment Programme (UNEP), created in 1972 by the UN General Assembly, the three last decades have seen the birth of several measures for the atmosphere safeguard.

It is rather difficult to recover a complete and up-to-date picture concerning atmospheric pollution. This paper sets the following objec-

\footnotetext{
* Corresponding Author: Tel.: +39 011 6708930; Fax: +39 011 6708798. E-mail address: chiara.bertora@unito.it
} 
tives: i) to provide an outline of the numerous scientific and legislative initiatives aimed at protecting the atmosphere; ii) to analyse in detail the agriculture sector in order to highlight both its contribution to atmospheric pollution and the actions aimed at preventing and mitigating it, specially focusing on climate change.

The main issues related to the atmospheric pollution are:

1) the stratospheric ozone depletion,

2) the transboundary air pollution and low-troposphere air quality, and

3) the climate change.

Table 1 lists the substances responsible of the different types of atmospheric pollution, specially referring to the contribute of agricultural activities.

\section{Stratospheric ozone depletion}

The first international treaty aiming at protecting the atmosphere within UNEP was the Montreal Protocol on Substances that Deplete the Ozone Layer (UNEP, 1987). The signature of this protocol was the result of a general warning engendered by the discovery of the Antarctic ozone $\left(\mathrm{O}_{3}\right)$ hole in the stratosphere by a research group from The British Antarctic Survey (Farman et al., 1985). The so-called ozone hole is a reduction of the total column ozone over Antarctica. Stratospheric $\mathrm{O}_{3}$ is in fact not measured in terms of concentration (that is normally of a few parts per billion), but in terms of ozone column thickness, expressed in Dobson Units (one DU refers to a thickness of $10 \mu \mathrm{m}$ at $1 \mathrm{~atm}$ and $273.15^{\circ} \mathrm{K}$ ). The normal ozone levels are observed to be around 300 DU.

The protocol parties (at present 191) have to control and eventually annul the emission to atmosphere of different Ozone-Depleting Substances (ODSs), such as halogenate hydrocarbons (chlorofluorocarbons or freons, bromofluorocarbons or halons), carbon tetrachloride, methyl chloroform and methyl bromide, all containing chlorine or bromine, both responsible of stratospheric ozone layer depletion. The Montreal Protocol stipulated that the production and consumption of ODSs are to be phased out by 2000 (2005 for methyl chloroform). At European level, ODSs emissions are regulated by Regulation 2037/2000/EC and its amendments.
Chlorofluorocarbons have been developed during 1930's as a non-toxic alternative to ammonia and have been largely employed since World War II as aerosol-spray propellants, refrigerants, solvents, and foam-blowing agents; bromofluorocarbons were mainly used in fire extinguishing systems; carbon tetrachloride was widely exploited as a dry cleaning solvent, as a refrigerant, and in fire extinguishers until 1940's, as a pesticide until 1970's and for the production of freon refrigerants prior to the Montreal Protocol; methyl chloroform is an excellent solvent for many organic materials and, prior to the Montreal Protocol, it was used for cleaning metal parts and circuit boards, as a photoresistent solvent in the electronics industry, as an aerosol propellant, and as a solvent for inks, paints, adhesives.

The role of chlorine compounds on $\mathrm{O}_{3}$ depletion was firstly theorized by Molina and Rowland (1974).

The role of agriculture activity in $\mathrm{O}_{3}$ depletion is linked to the utilization of methyl bromide, an excellent soil sterilant used for more than 40 year as pre-plant soil fumigant for highvalue crops (Kabir et al., 2005); the phase-out of methyl bromide has engendered the need to explore valid alternatives, currently still in progress (Rugutt et al., 2006). A further contribution is also given by the emission of nitrogen oxides and their precursor, nitrous oxide, from agricultural soils.

The unnatural depletion of the Antarctic $\mathrm{O}_{3}$ observed in the last three decades must not be confused with the natural decline of the $\mathrm{O}_{3}$ layer over the two poles during winter and spring due to climatologic reasons. The unique meteorological conditions occurring in the polar stratosphere at the beginning of springtime includes the presence of the polar vortex, that is a tropospheric and stratospheric current, isolating a large mass of air over the two poles from adjacent air masses. The polar vortex is more pronounced during respective hemisphere winter in both poles. Ozone column reduction is also related to the extremely cold temperature and the presence of Polar Stratospheric Clouds (PSCs), that, through heterogeneous reactions, catalyse the formation of chlorine from $\mathrm{ClONO}_{2}$ and $\mathrm{HCl}$ and, due to the presence of $\mathrm{HNO}_{3}$, prevent the reversibility of this reaction (Hopfner et al., 2006). The occurrence of the 
Table 1. List of substances responsible of air pollution. Full cells indicate a contribution of the corresponding substance to that type of pollution. Letters L (low), M (medium), and H (high) indicate the importance of the agriculture sector in the emission of each substance.

\begin{tabular}{|c|c|c|c|c|c|}
\hline Pollutant & Description & $\begin{array}{l}\text { Stratospheric } \\
\text { ozone } \\
\text { depletion }\end{array}$ & $\begin{array}{l}\text { Trans- } \\
\text { boundary } \\
\text { air pollution }\end{array}$ & $\begin{array}{l}\text { Low- } \\
\text { troposphere } \\
\text { air quality }\end{array}$ & $\begin{array}{l}\text { Climate } \\
\text { change }\end{array}$ \\
\hline Aerosols & $\begin{array}{l}\text { Sulphate aerosols, nitrate aerosols, } \\
\text { organic aerosols, black carbon, } \\
\text { mineral dust aerosols }\end{array}$ & & & & $\mathrm{L}$ \\
\hline $\mathrm{CH}_{4}$ & Methane & & & & $\mathrm{H}$ \\
\hline $\mathrm{CO}$ & Carbon monoxide & & M & M & \\
\hline $\mathrm{CO}_{2}$ & Carbon dioxide & & & & M \\
\hline $\mathrm{H}_{2} \mathrm{O}$ & Water vapour & & & & M \\
\hline Heavy Metals & Cadmium $(\mathrm{Cd})$, Lead $(\mathrm{Pb})$, Mercury $(\mathrm{Hg})$ & & $\mathrm{L}$ & $\mathrm{L}$ & \\
\hline $\mathrm{N}_{2} \mathrm{O}$ & Nitrous oxide & $\mathrm{H}$ & & & $\mathrm{H}$ \\
\hline $\mathrm{NH}_{3}$ & Ammonia & & $\mathrm{H}$ & & \\
\hline NMVOCs & $\begin{array}{l}\text { Non Methane Volatile Organic Compounds } \\
\text { (e.g. aldehydes, ketones, and hydrocarbons) }\end{array}$ & & $\mathrm{L}$ & $\mathrm{L}$ & \\
\hline $\mathrm{NO}_{\mathrm{x}}$ & Nitrogen oxides $\left(\mathrm{NO}, \mathrm{NO}_{2}\right)$ & $\mathrm{M}$ & $\mathrm{M}$ & $\mathrm{M}$ & \\
\hline$\overline{\mathrm{O}_{3}}$ & Tropospheric ozone & & $\mathrm{L}$ & $\mathrm{L}$ & \\
\hline ODSs & $\begin{array}{l}\text { Ozone Depleting Substances } \\
\text { (chlorofluorocarbons, bromofluorocarbons, } \\
\text { carbon tetrachloride, methyl chloroform and } \\
\text { methyl bromide) }\end{array}$ & $\mathrm{L}$ & & & $\mathrm{L}$ \\
\hline$\overline{\mathrm{OH}^{-}}$ & Hydroxyl radical & & & & $\mathrm{L}$ \\
\hline PAN & Peroxiacyl nitrates & & $\mathrm{L}$ & & \\
\hline POPs & $\begin{array}{l}\text { Persistent Organic Pollutants (Aldrin, } \\
\text { Chlordane, Chlordecone, DDT, Dieldrin, } \\
\text { Endrin, Heptachlor, HCH, Hexachlorobenzene, } \\
\text { Mirex, Toxaphene, Polychlorinated biphenyls } \\
\text { PCBs, Hexabromobiphenyl, Dioxins, Furans, } \\
\text { Polycyclic Aromatic Hydrocarbons PAHs) }\end{array}$ & & $\mathrm{H}$ & & \\
\hline $\mathrm{SO}_{2}$ & Sulphur dioxide & & $\mathrm{L}$ & $\mathrm{L}$ & \\
\hline
\end{tabular}

ozone layer reduction is periodical and mainly takes place during springtime, since the presence of sunlight catalyses $\mathrm{O}_{3}$ dissociation after a long dark winter period.

This phenomenon is more accentuated over the Antarctica than over the Artic. The different land distribution rends in fact the South Pole colder than the North Pole, and the different orography generates a greater air mixing over the North Pole (Karentz and Bosch, 2001). Ozone depletion has been later measured everywhere outside the tropics (Staehelin et al., 1998), even though the gravity of the phenomenon is minor than over Antarctica.

ODSs, once arrived to the stratosphere, are broken down by the ultraviolet radiation, freeing chlorine and bromine, potentially able to interact with the ozone molecules. As exhaustively described in the review by Solomon (1999), ozone photolysis in the stratosphere was already known during 1930's, when Chapman (1930) first observed the rapid interchange of ozone and atomic oxygen: from the photolysis of ozone, atomic oxygen is produced and nearly all the atomic oxygen reforms the ozone in few seconds $\left(\mathrm{O}_{3}+\mathrm{h} v \rightarrow \mathrm{O}+\mathrm{O}_{2} ; \mathrm{O}+\mathrm{O}_{2} \rightarrow \mathrm{O}_{3}\right)$ and a very small fraction of them can react with ozone forming $\mathrm{O}_{2}\left(\mathrm{O}+\mathrm{O}_{3} \rightarrow 2 \mathrm{O}_{2}\right)$. Soon after it became clear that other substances could chemically react with the ozone in an analogous way as atom- 
ic oxygen, such as for example the hydroxyl $\left(\mathrm{OH}^{-}\right)$ (Bates and Nicolet, 1950) and the nitric oxide (NO) (Crutzen, 1970). Both these substances act as catalyst of ozone destruction, but are not themselves consumed (Taylor, 2005), therefore small quantities are enough to interact with a great amount of ozone. The following reactions are possible: for $\mathrm{OH}^{-}, \mathrm{OH}+\mathrm{O}_{3} \rightarrow \mathrm{HO}_{2}+\mathrm{O}_{2} ; \mathrm{HO}_{2}$ $+\mathrm{O}_{3} \rightarrow \mathrm{OH}+2 \mathrm{O}_{2}$; for $\mathrm{NO}, \mathrm{NO}+\mathrm{O}_{3} \rightarrow \mathrm{NO}_{2}+$ $\mathrm{O}_{2} ; \mathrm{O}+\mathrm{NO}_{2} \rightarrow \mathrm{NO}+\mathrm{O}_{2}$. Chlorine and bromine were later identified as involved in a catalytic cycle resulting in ozone destruction, following these reactions: $\mathrm{Cl}+\mathrm{O}_{3} \rightarrow \mathrm{ClO}+\mathrm{O}_{2} ; \mathrm{ClO}+\mathrm{O}$ $\rightarrow \mathrm{Cl}+\mathrm{O}_{2}$ and $\mathrm{Cl}+\mathrm{O}_{3} \rightarrow \mathrm{ClO}+\mathrm{O}_{2} ; \mathrm{Br}+\mathrm{O}_{3}$ $\rightarrow \mathrm{BrO}+\mathrm{O}_{2} ; \mathrm{BrO}+\mathrm{ClO} \rightarrow \mathrm{Br}+\mathrm{ClO}_{2} ; \mathrm{ClO}_{2}$ $\rightarrow \mathrm{Cl}+\mathrm{O}_{2}$ (Stolarski and Cicerone, 1974; Yung et al., 1980).

The stratospheric ozone absorbs specific wavelength radiations and it is recognized that its reduction does not only modifies the thermal structure of the stratosphere and therefore of the whole atmosphere (resulting in indeterminate environmental and climatic effects), but also increases ultraviolet (UV) transmission, affecting human, animal and plants health. UV is strongly absorbed by superficial tissues and damages eye and skin, inducing also severe disorders, such as skin cancers (de Gruijl et al., 2003). Furthermore the increased penetration of UV in the troposphere results in additional production of ground level ozone, which causes respiratory illnesses, as better described below. The alteration of the amount of UV radiation reaching the earth surface can alter the terrestrial and aquatic ecosystems equilibrium (Shick et al., 1996; Young, 1997).

As a result of the Montreal Protocol application, the production and consumption of ODSs have been drastically reduced if compared with the baseline year (UNEP, 2005). Following data from US Environmental Protection Agency (EPA), the ozone layer depletion ceased since 1998 and the Antarctic ozone is projected to return to pre-1980 levels by 2060 to 2075 (EPA, 2007).

\section{Transboundary air pollution and low-tropos- phere air quality}

\subsection{Transboundary air pollution}

In 1979, for the initiative of the United Nations Economic Commission for Europe (UNECE),
34 governments and the European Community signed the Convention on Long-Range Transboundary Air Pollution (CLRTAP) (UNECE, 1979). At present, 51 countries in Europe, North America and Asia have ratified the convention. During its history, this convention, receiving scientific support by EMEP (European Monitoring and Evaluation Programme - Steering Body to the Cooperative Programme for Monitoring and Evaluation of the Long-range Transmission of Air Pollutants in Europe), was extended by eight different protocols identifying specific measures to cut the emissions of different air pollutants. The activities under the Convention initially focused on reducing the effects of acid rain through the reduction of sulphur dioxide $\left(\mathrm{SO}_{2}\right)$ (UNECE, 1985; UNECE, 1994) and nitrogen oxides $\left(\mathrm{NO}_{\mathrm{x}}\right)$ emissions (UNECE, 1988). Later, the scope was widened to the control of volatile organic compounds (VOCs) (UNECE, 1991), heavy metals (UNECE, 1998a) and persistent organic pollutants (POPs) (UNECE, 1998b) and, more recently, the formation of ground level ozone (photochemical smog) and overall agents of acidification and eutrophication (UNECE, 1999). EMEP provides reports on the emissions, concentrations and/or depositions of air pollutants, the quantity and significance of transboundary fluxes.

The substances responsible of the transboundary air pollution are: sulphur dioxide, nitrogen oxides, ammonia, non methane volatile organic compounds, carbon monoxide, heavy metals, persistent organic pollutants, and tropospheric ozone.

Sulphur dioxide. Anthropogenic sulphur is mainly released by the combustion of fossil fuels, but it is also produced in petroleum refinement, in the production of heavy metals from sulphidic ores, in the production of sulphuric acid, paper and sulphur.

The agriculture activity is not significantly involved in $\mathrm{SO}_{2}$ production, but is strongly influenced by it. The emission and successive deposition of sulphur can in fact affect and damage soils, forests and freshwaters, as originally observed in northern Europe lakes during 1970's (Hendrey and Wright, 1975; Oden, 1968). Although the very first alarm linked with sulphur emissions was related to acidic depositions, currently the interest is rather focused on hu- 
man health impact of the long-term exposure to particulate sulphur and the cooling effect of sulphate aerosols (Myhre et al., 2004). $\mathrm{SO}_{2}$ (together with non methane VOCs, $\mathrm{NO}_{\mathrm{x}}$ and carbon monoxide) is also considered as a precursor of the tropospheric $\mathrm{O}_{3}$. Besides the CLRTAP protocols (UNECE 1985; UNECE, 1994; UNECE 1999), sulphur emissions are regulated at European level by the National Emission Ceilings (NEC) Directive 2001/81/EC (EC, 2001a). Upper limits for each Member State for the total emissions in 2010 of the four pollutants responsible for acidification, eutrophication and ground-level ozone pollution, i.e. sulphur dioxide, nitrogen oxides, volatile organic compounds and ammonia, are defined. NEC targets are more ambitious than those of CLRTAP. These and several other specific directives are listed in Table 2.

At the European level, the total sulphur target for 2010 set in the Gothenburg Protocol (UNECE, 1999) has apparently already been met by 2004, but still half of the Parties have to reduce further their sulphur emissions in order to attain their individual emission target (EMEP, 2004; Vestreng et al., 2007).

Nitrogen oxides. Nitrogen oxides $\left(\mathrm{NO}_{\mathrm{x}}=\mathrm{NO}_{2}\right.$ and $\mathrm{NO}$ ) are mainly produced from air oxygen and nitrogen during combustion in energy production plants and in vehicles.

Agricultural soil are a potential source of $\mathrm{NO}$ as a consequence of $\mathrm{N}$ fertilization (Meijide et al., 2007). NO, as well as nitrous oxide $\left(\mathrm{N}_{2} \mathrm{O}\right)$, is produced through nitrification and denitrification; albeit it is clear that the factors affecting its production are on the whole the same (see below), the mechanisms leading to its production are generally less investigated than for $\mathrm{N}_{2} \mathrm{O}$ (Garrido et al., 2002; Pinto et al., 2004).

When dissolved in water, nitric oxide forms nitric acid, thus being an agent of acidification (Galloway and Likens, 1981). Furthermore, its deposition can cause eutrophication, i.e. an unnatural increase of $\mathrm{N}$ availability for the ecosystems.

$\mathrm{NO}_{\mathrm{x}}$ emissions are regulated by the Protocol of Gothenburg (UNECE, 1999) and the NEC Directive (EC, 2001a) as agents of acidification and eutrophication and precursors of tropospheric ozone, by Directives limiting the emissions from vehicles, dealing with stationary source emissions, and protecting wild plants, animals and habitats from eutrophication (Tab. 2).

The European emissions showed a downward trend between 1980 and 2000, producing a reduction of approximately $25 \%$ (EMEP, 2004).

Ammonia. The largest source of ammonia $\left(\mathrm{NH}_{3}\right)$ emissions is the agriculture sector, through the use of synthetic or biologically fixed nitrogen (atmospheric nitrogen that has been incorporated into a nitrogen-containing compound by plants) and the manure management.

$\mathrm{NH}_{3}$ is released to the atmosphere from agricultural soils because of the biological degradation of soil organic matter and the supply of mineral and organic fertilizers, leading to high availability of ammonium $\left(\mathrm{NH}_{4}^{+}\right)$. The dynamic equilibrium between $\mathrm{NH}_{4}^{+}$and $\mathrm{NH}_{3}$ is function of several factors, mainly physical, such as temperature, cationic exchange capacity, $\mathrm{pH}$, and water content. Ammonium solubility in water is reduced by high temperatures, thus resulting in a high $\mathrm{NH}_{3}$ to $\mathrm{NH}_{4}^{+}$proportion (Liu et al., 2007); $\mathrm{NH}_{4}^{+}$is retained on the negatively charges of soil colloids, resulting in a negative correlation between $\mathrm{CEC}$ and $\mathrm{NH}_{3}$ (Fenn and Kissel, 1976); under elevated $\mathrm{pH}$ condition, $\mathrm{NH}_{4}{ }^{+}$tends to turn into $\mathrm{NH}_{3}$ releasing $\mathrm{H}^{+}$ions (Chantigny et al., 2004); soil moisture controls both $\mathrm{NH}_{4}^{+}$formation and volatilisation (Le Cadre et al., 2005). The $\mathrm{NH}_{3}$ volatilisation is lead by the difference in $\mathrm{NH}_{3}$ partial pressure between the atmosphere immediately close to soil surface and in soil atmosphere. As a result, volatilisation is also controlled by the wind speed and the atmospheric turbulences (Meyers et al., 2006).

The management practices determining the $\mathrm{NH}_{3}$ volatilisation include the choice of the type of fertilizer and the fertilizer application method. Among the most used mineral fertilizers the highest potential for volatilisation is that of ammonium nitrate followed by urea; the lowest values are those of anhydrous ammonia and calcium nitrate (FAO and IFA, 2001). The rapid incorporation of fertilizer into the soil, the use of urease inhibitors, coupling $\mathrm{N}$ fertilizers with phosphoric acids or the addition of zeolites are as well indicated as $\mathrm{NH}_{3}$ losses reducing techniques (Ahmed et al., 2006; Byrnes, 1990; Watson et al., 1994). 
Table 2. Main international and European regulations dealing with air pollution.

\begin{tabular}{|c|c|c|}
\hline Regulation & Aims & Substances \\
\hline \multicolumn{3}{|l|}{ International regulations } \\
\hline $\begin{array}{l}\text { Convention on Long-Range } \\
\text { Transboundary Air Pollution } \\
\text { (UNECE, 1979) }\end{array}$ & $\begin{array}{l}\text { Limitation, reduction and prevention of air } \\
\text { pollution including long-range transboundary } \\
\text { air pollution. It is articulted in } 8 \text { specific Protocols }\end{array}$ & $\begin{array}{l}\text { Those interested by } \\
\text { the } 8 \text { Protocols }\end{array}$ \\
\hline $\begin{array}{l}\text { Protocol of Helsinki (UNECE, 1985) } \\
\text { under CLRTAP }\end{array}$ & $\begin{array}{l}\text { Reduction of sulphur emissions or their } \\
\text { transboundary fluxes by at least } 30 \text { per cent }\end{array}$ & $\mathrm{SO}_{2}$ \\
\hline Protocol of Montreal (UNEP, 1987) & Control of ozone-depleting substances & ODSs \\
\hline $\begin{array}{l}\text { Protocol of Sofia (UNECE, 1988) } \\
\text { under CLRTAP }\end{array}$ & $\begin{array}{l}\text { Control of emissions of nitrogen oxides or } \\
\text { their transboundary fluxes }\end{array}$ & $\mathrm{NO}_{\mathrm{x}}$ \\
\hline $\begin{array}{l}\text { Protocol of Geneva (UNECE, 1991) } \\
\text { under CLRTAP }\end{array}$ & $\begin{array}{l}\text { Reduction of volatile organic compounds or } \\
\text { their transboundary fluxes by at least } 30 \text { per cent }\end{array}$ & NMVOCs \\
\hline $\begin{array}{l}\text { Protocol of Oslo (UNECE, 1994) } \\
\text { under CLRTAP }\end{array}$ & Further reduction of sulphur emissions & $\mathrm{SO}_{2}$ \\
\hline $\begin{array}{l}\text { United Nation Framework } \\
\text { Convention on Climate Change } \\
\text { (UN, 1992) and Protocol of Kyoto } \\
\text { (UNFCCC, 1997) }\end{array}$ & $\begin{array}{l}\text { Reduction of the emission of the greenhouse } \\
\text { gases not included in the Protocol of Montreal }\end{array}$ & $\begin{array}{l}\mathrm{CO}_{2}, \mathrm{CH}_{4}, \mathrm{~N}_{2} \mathrm{O} \\
\mathrm{HFCs}, \mathrm{PFCs}, \mathrm{SF}_{6}\end{array}$ \\
\hline $\begin{array}{l}\text { Protocol of Aarhaus (UNECE, 1998a) } \\
\text { under CLRTAP }\end{array}$ & $\begin{array}{l}\text { Control of emissions of cadmium, lead and } \\
\text { mercury }\end{array}$ & $\mathrm{Cd}, \mathrm{Pb}, \mathrm{Hg}$ \\
\hline $\begin{array}{l}\text { Protocol of Aarhaus (UNECE, 1998b) } \\
\text { under CLRTAP }\end{array}$ & $\begin{array}{l}\text { Elimination of any discharges, emissions and } \\
\text { losses of POPs }\end{array}$ & POPs \\
\hline $\begin{array}{l}\text { Protocol of Gothenburg } \\
\text { (UNECE, 1999) under CLRTAP }\end{array}$ & Further reduction of $\mathrm{SO}_{2}, \mathrm{NO}_{\mathrm{x}}, \mathrm{VOCs}, \mathrm{NH}_{3}$ & $\begin{array}{l}\mathrm{SO}_{2}, \mathrm{NO}_{\mathrm{x}}, \mathrm{VOCs} \\
\mathrm{NH}_{3}, \mathrm{CO}\end{array}$ \\
\hline Stockolm Convention (2001) & $\begin{array}{l}\text { Elimination of any discharges, emissions } \\
\text { and losses of POPs }\end{array}$ & POPs \\
\hline \multicolumn{3}{|l|}{ European directives or regulations } \\
\hline $\begin{array}{l}\text { Directive 1970/220/EEC (EEC, 1970) } \\
\text { and its amendments (last one: } \\
\text { Directive 98/70/EC; EC, 1998) }\end{array}$ & $\begin{array}{l}\text { Setting of the emission standards from } \\
\text { light-duty vehicles }\end{array}$ & $\begin{array}{l}\mathrm{CO}, \mathrm{NMVOCs}, \mathrm{NO}_{\mathrm{x}} \\
\mathrm{PM}\end{array}$ \\
\hline $\begin{array}{l}\text { Directive 1992/43/EC (EU Habitat } \\
\text { Directive) (EEC, 1992) }\end{array}$ & Protect the wild plants, animals and habitats & $\mathrm{NO}_{\mathrm{x}}, \mathrm{NH}_{3}$ \\
\hline Directive 1994/63/EC (EC, 1994) & $\begin{array}{l}\text { Regulations of VOCs emissions from the } \\
\text { storage of petrol and its distribution from } \\
\text { terminals to service stations }\end{array}$ & VOCs \\
\hline $\begin{array}{l}\text { Directive 1999/13/EC (VOC } \\
\text { Solvents Directive) (EC, 1999a) }\end{array}$ & $\begin{array}{l}\text { Reduction of industrial emissions of volatile } \\
\text { organic compounds }\end{array}$ & VOCs \\
\hline $\begin{array}{l}\text { Directive 1999/30/EC (EC, 1999b) } \\
\text { (First Daughter Directve, from } \\
\text { Directive 1996/62/EC or Air Quality } \\
\text { Framework Directive; EC, 1996a) }\end{array}$ & $\begin{array}{l}\text { Limitations for } \mathrm{SO}_{2}, \mathrm{NO}_{\mathrm{x}}, \mathrm{PM} \text { and } \mathrm{Pb} \\
\text { concentration in air }\end{array}$ & $\begin{array}{l}\mathrm{SO}_{2}, \mathrm{NO}_{x}, \mathrm{PM} \\
\left.\text { (therefore } \mathrm{NH}_{3}\right), \mathrm{Pb}\end{array}$ \\
\hline Directive 1999/32/EC (EC, 1999c) & Reduction of sulphur content of certain liquid fuels & $\mathrm{SO}_{2}$ \\
\hline $\begin{array}{l}\text { Directive 2000/69/EC (EC, 2000b) } \\
\text { (Second Daughter Directive, from } \\
\text { Directive 1996/62/EC or Air Quality } \\
\text { Framework Directive; EC, 1996a) }\end{array}$ & $\begin{array}{l}\text { Limitations for benzene and CO concentration } \\
\text { in air }\end{array}$ & Benzene (POP), CO \\
\hline $\begin{array}{l}\text { Directive 2000/76/EC (Waste } \\
\text { Incineration DirectiveEC, 2000a) }\end{array}$ & $\begin{array}{l}\text { Reduction emissions of pollutant to the } \\
\text { environment (air, soil, surface water and } \\
\text { groundwater) caused by the incineration and } \\
\text { co-incineration of wastes }\end{array}$ & $\begin{array}{l}\mathrm{SO}_{2}, \mathrm{NO}_{x} \text {, heavy } \\
\text { metals, } \mathrm{PM},(\mathrm{HCl}) \\
\text { dioxines, furans }\end{array}$ \\
\hline
\end{tabular}




\begin{tabular}{|c|c|c|}
\hline Regulation & Aims & Substances \\
\hline \multicolumn{3}{|l|}{ European directives or regulations } \\
\hline $\begin{array}{l}\text { Regulation 2037/2000/EC and its } \\
\text { amendments (EC, 2000c) }\end{array}$ & Control of ozone-depleting substances & ODSs \\
\hline $\begin{array}{l}\text { Directive 2001/80/EC (Large } \\
\text { Combustion Plants Directive; } \\
\text { EC, 2001b) }\end{array}$ & $\begin{array}{l}\text { Reduction of emissions of acidifying pollutants, } \\
\text { particles and ozone precursors from large } \\
\text { combustion plants }\end{array}$ & $\mathrm{SO}_{2}, \mathrm{NO}_{\mathrm{x}}$ \\
\hline $\begin{array}{l}\text { Directive 2001/81/EC (National } \\
\text { Emission Ceilings Directive; } \\
\text { EC, 2001a) }\end{array}$ & $\begin{array}{l}\text { Settings of upper limits for each Member State } \\
\text { for the total emissions in } 2010 \text { of the four } \\
\text { pollutants responsible for acidification, } \\
\text { eutrophication and ground-level ozone pollution }\end{array}$ & $\mathrm{SO}_{2}, \mathrm{NO}_{\mathrm{x}}, \mathrm{VOCs}, \mathrm{NH}_{3}$ \\
\hline $\begin{array}{l}\text { Directive 2002/03/EC (EC, 2002) } \\
\text { (Third Daughter Directive, from } \\
\text { Directive 1996/62/EC or Air Quality } \\
\text { Framework Directive; EC, 1996a) }\end{array}$ & Limitations for $\mathrm{O}_{3}$ concentration in air & $\mathrm{O}_{3}$ \\
\hline $\begin{array}{l}\text { Directive 2004/42/EC (Paints } \\
\text { Directive; EC, 2004a) }\end{array}$ & $\begin{array}{l}\text { Limitations for the maximum VOC contents of } \\
\text { decorative paints and other products }\end{array}$ & VOCs \\
\hline $\begin{array}{l}\text { Directive 2004/107/EC (EC, 2004b) } \\
\text { (Fourth Daughter Directive, from } \\
\text { Directive 1996/62/EC or Air Quality } \\
\text { Framework Directive; EC, 1996a) }\end{array}$ & $\begin{array}{l}\text { Limitations for As, } \mathrm{Cd}, \mathrm{Hg}, \mathrm{Ni} \text { and PAHs } \\
\text { concentration in air }\end{array}$ & As, $\mathrm{Cd}, \mathrm{Hg}, \mathrm{Ni}, \mathrm{PAHs}$ \\
\hline Directive 2005/55/EC (EC, 2005) & $\begin{array}{l}\text { Setting of the emission standards from } \\
\text { heavy-duty vehicles }\end{array}$ & $\begin{array}{l}\mathrm{CO}, \mathrm{NMVOCs}, \mathrm{NO}_{\mathrm{x}} \\
\mathrm{PM}\end{array}$ \\
\hline $\begin{array}{l}\text { Directive 2008/1/EC (Integrated } \\
\text { Pollution Prevention and Control } \\
\text { Directive-IPPC; EC, 2008) replacing } \\
\text { the Directive 1996/61/EC (EC, 1996b) }\end{array}$ & $\begin{array}{l}\text { Minimising pollution from various industrial } \\
\text { sources }\end{array}$ & $\begin{array}{l}\mathrm{SO}_{2}, \mathrm{NO}_{\mathrm{x}}, \mathrm{VOCs}, \\
\mathrm{NH}_{3}, \mathrm{CO} \text {, heavy } \\
\text { metals, POPs }\end{array}$ \\
\hline
\end{tabular}

Manure management, including storage and field application, is responsible of significant $\mathrm{NH}_{3}$ emissions. As for $\mathrm{NH}_{3}$ emitted by soils, the key factors determining $\mathrm{NH}_{3}$ losses from manure storage are temperature and wind conditions; furthermore manure composition and manure management are also crucial (Balsari et al., 2007). Some technical improvement are possible, such as increasing animal $\mathrm{N}$ retention through a correct diet, directly incorporating manure into the soil, covering of the manure storage, diluting or acidifying manure (Bussink and Oenema, 1998).

$\mathrm{NH}_{3}$ emitted to atmosphere promptly reacts with nitrate and sulphate (in their turn formed by oxidation of $\mathrm{NO}_{2}$ and $\mathrm{SO}_{2}$ ) to form particulates, prolonging its permanence in atmosphere and being potentially transported elsewhere. It is subsequently deposited to the land and water as dry deposition of $\mathrm{NH}_{3}$ or dry and wet deposition of $\mathrm{NH}_{4}{ }^{+}$(Asman and Vanjaarsveld, 1992). $\mathrm{NH}_{3}$ is recognized as one of the many precur- sors to both coarse and fine particulate matter (PM), along with other gaseous precursors such as $\mathrm{NO}, \mathrm{NO}_{2}, \mathrm{NMVOCs}$ and $\mathrm{SO}_{2}$. When dissolved in rainwater, it has tendency to increase rain $\mathrm{pH}$, but once in the soil, it can be nitrified and therefore induce soil acidification, even though this source of acidification is considered less serious than dry and wet deposition of free acids (Van Breemen et al., 1982). Moreover, $\mathrm{N}$ deposition (of $\mathrm{NH}_{3}$ and $\mathrm{NO}_{\mathrm{x}}$ ) directly or indirectly contributes to many other environment issues, such as drink water quality, eutrophication of estuaries, nitrate-induced toxic effects on freshwater biota, changes in plant community composition, disruptions in nutrient cycling, and increased emissions from soil of nitrogenous greenhouse gases (Fenn et al., 1998; Fenn et al., 2003).

$\mathrm{NH}_{3}$ emissions are regulated by the Protocol of Gothenburg (UNECE, 1999) and, at European level, by the stationary source emissions Directives, by the Habitat (EEC, 1992) and NEC Directives (EC, 2001a) (Tab. 2). 
Following data from the last european CLRTAP inventory report, EU-15 countries on average reduced $\mathrm{NH}_{3}$ emissions by approximately $12 \%$ in the period $1990-2005$ (EEA, 2007).

Non-Methane Volatile Organic Compounds. Volatile Organic Compounds (VOCs) are organic compounds that have a high enough vapour pressure under normal conditions to significantly vaporize and enter the atmosphere; several carbon-based molecules, such as aldehydes, ketones, and hydrocarbons are VOCs. The main VOC is methane $\left(\mathrm{CH}_{4}\right)$ while the others are often defined as NMVOCs (Non-Methane Volatile Organic Compounds).

Artificial sources of NMVOCs are paint and dry cleaning solvents and petroleum fuels (benzene, toluene, and xylene) and, indoor, photocopiers, furniture and other components treated with some substances (formaldehyde, tetrachloroethylene and trichloroethylene).

Agriculture contribution is quite limited, including only the emissions of NMVOCs, such as dimethyl sulphides, volatile fatty acids or phenols, from animal manure (Hobbs et al., 2004).

Their hazard is mainly linked with human health, since some of them are carcinogenic (Boeglin et al., 2006) and particulate matter precursors. The risk for the environment is instead related to the tropospheric ozone formation, of which NMVOCs are precursors.

The emission to the atmosphere of these substances is regulated by CLRTAP protocols (UNCE, 1991; UNCE, 1999), the NEC Directive (EC, 2001a), and by several other Directives (Tab. 2).

Following data from the European Environment Agency (EEA), the EU15 emissions of NMVOCs have been reduced by $32 \%$ between 1990 and 2001.

Carbon monoxide. Carbon monoxide (CO) is formed when carbon-containing fuels are burned incompletely and it is naturally oxidized in atmosphere to $\mathrm{CO}_{2}$.

The contribution of the agriculture is related to the soil-atmosphere $\mathrm{CO}$ exchanges, that are the abiological production and the microbiological consumption. The balance of these two processes is prone to be modified by agricultural practices. $\mathrm{N}$ fertilization and SOM-modifying practices can act in both directions (Chan and Steudler, 2006; Moxley and Smith, 1998).

$\mathrm{CO}$ is involved in the tropospheric $\mathrm{O}_{3}$ dynamics, with opposite effects: directly is one of the $\mathrm{O}_{3}$ precursors, and indirectly reacts with some atmospheric constituents, such as hydroxyl radical $\left(\mathrm{OH}^{-}\right)$, that would otherwise destroy ozone (and also methane) (Novelli et al., 1994). Outdoor and indoor exposure to $\mathrm{CO}$ can lead to severe consequences for human health (Chen et al., 2007).

Its emissions are internationally regulated by the Protocol of Gothenburg (UNECE, 1999) and at European level by Directives dealing with emissions from vehicles and from stationary sources (Tab. 2).

Heavy metals. Heavy metals (mainly cadmium, lead and mercury) are produced from industrial processes, such as combustion of fossil fuels, iron and steel industry, cement, glass and chloralkali industry, waste incineration.

Albeit agriculture is not significantly involved in heavy metals production, the related effects interest this sector. Heavy metals have in fact high toxicity and persistence in the environment, can accumulate in the soil, seriously affecting microbial biomass and activity (Baath, 1989), water, air and plants and, through the food chain, can alter animal and human health (Jarup, 2003).

Their emissions to the atmosphere is regulated by the CLRTAP Protocol of Aarhaus (UNECE, 1998a) and its industrial production by the Integrated Pollution Prevention and Control (IPPC) (EC, 2008), and Waste Incineration (EC, 2000a) Directives (Tab. 2).

Persistent Organic Pollutants. Persistent Organic Pollutants (POPs) are 11 pesticides (Aldrin, Chlordane, Chlordecone, DDT, Dieldrin, Endrin, Heptachlor, $\mathrm{HCH}$, Hexachlorobenzene, Mirex, Toxaphene), two industrial chemicals (Polychlorinated biphenyls PCBs and Hexabromobiphenyl) and three by-products/contaminants (Dioxins, Furans, Polycyclic Aromatic Hydrocarbons-PAHs).

The agriculture has strongly contributed in the past years to the emission of the majority of these substances, largely used as insecticides and fungicides.

They are found to resist photolytic, biological and chemical degradation, have a high lipid 
solubility leading to bioaccumulation in fatty tissues and move to long distances because of their semi-volatility (Ritter et al., 2007). They have been associated with both carcinogenic and endocrine disrupting effects in a range of biota $(\mathrm{Li}$ et al., 2006).

They are regulated at international level by the Convention of Stockholm (covering 12 substances) and by the Protocol of Aarhaus (covering 16 substances) (UNECE, 1998b). Their production from punctual sources is regulated at European level by the IPPC (EC, 2008), Waste Incineration (EC, 2000a), and Paints (EC, 2004a) Directives (Tab. 2).

Tropospheric ozone. Tropospheric $\mathrm{O}_{3}$ and peroxyacyl nitrates (PAN) are the major component of the photochemical smog. Tropospheric $\mathrm{O}_{3}$ is formed from a complex set of chemical reactions involving ultraviolet radiation, NMVOCs, $\mathrm{NO}_{\mathrm{x}}$, and $\mathrm{CO}$. This phenomenon occurs under specific environmental conditions, specially the sunlight and the absence of precipitations and wind. The risk of photochemical smog is increased by the reduction of stratospheric $\mathrm{O}_{3}$.

Tropospheric $\mathrm{O}_{3}$ concentration values are based on simulation models driven by the emissions of the precursors $\left(\mathrm{NO}_{\mathrm{x}}, \mathrm{CO}, \mathrm{NMVOCs}\right.$ and $\mathrm{CH}_{4}$ ) and the tropospheric $\mathrm{O}_{3}$ layer thickness. The use of simulation models, e.g. ACCENT, is necessary, due to the inadequate measurements of tropospheric $\mathrm{O}_{3}$ concentration (Gauss et al., 2006).

Tropospheric $\mathrm{O}_{3}$ concentrations show a seasonal trend, becoming particularly high in summertime in regions with high emissions from traffic and industry. During the day, $\mathrm{O}_{3}$ is build up and peaks in the afternoon while at nighttime ozone concentrations decline.

Tropospheric $\mathrm{O}_{3}$ and PAN are responsible of human diseases like asthma (Stieb et al., 1996), and of injury to materials and to vegetation (Fuhrer et al., 1997). Tropospheric $\mathrm{O}_{3}$ is also recognized as a greenhouse gas.

The regulation of the emission of these substances is included in the Protocol of Gothenburg and in the NEC Directive (Tab. 2).

\subsection{Low-troposphere air quality}

Most substances responsible of the transboundary pollution have negative effects on human health. The main international body involved in combating low troposphere air pollution and regulating air quality is the World Health Organization (WHO), a specialized agency of the United Nations established in 1948. The specific WHO air quality program is responsible of reviewing the scientific evidence on health effects of air pollution and publishing the global "WHO Air Quality Guidelines" for a range of air pollutants. This is the basis for the EU legislation on air quality.

European Union carried out a complete revision of the air quality legislation during 1990s, resulting in the creation of the Air Quality Framework Directive 1996/62/EC (EC, 1996a). It describes the basic principles about how air quality should be assessed and managed in the Member States and provides a list of pollutants to control. Each Member State has to divide its territory in zones (parts of the territory) and agglomerations (zones with a population density of more than 250000 inhabitants per $\mathrm{km}^{2}$ or with a lower density but still needing a specific air quality assessment). Air quality measurements are mandatory for the agglomerations and for the zones where the measured concentrations exceed the thresholds; where the levels are below the limits, the sole use of modelling or objective estimation techniques for assessing levels is possible. Where pollutants have to be measured, the measurements shall be taken at fixed sites either continuously or by random sampling; the number of measurements has to be sufficiently large to enable the levels observed to be determined. In the zones and agglomerations with levels of one or more pollutants higher than the limit value plus the margin of tolerance, the Member State has to prepare a plan to attain the limit values within a certain time span.

The existing air quality European legislation is currently under revision under the Clean Air for Europe (CAFE) Programme, launched in 2001 for the development of a Thematic Strategy on Air Pollution within the Sixth Environment Action Programme (6EAP). Analysis under CAFE programme highlighted the inadequacy of existing legislation about particulate matter pollution. As a result, the European Commission has recently (september 2005) adopted a proposal for a new air quality directive, currently under reading, that has still to be 
approved both by the Council of Ministers and the European Parliament.

At present the concentration of $\mathrm{SO}_{2}$ has strongly decreased and attention has been definitely shifted on other pollutants strongly dangerous for human health, such as tropospheric $\mathrm{O}_{3}, \mathrm{NO}_{\mathrm{x}}$ and particulate matter.

Particulate matter is a mixture of solid and liquid particles suspended in the air. While large particles are mainly solid, small particles are largely formed by gases. They are subjected to a size distinction between $\mathrm{PM}_{10}($ size $\leq 10 \mu \mathrm{m})$, $\mathrm{PM}_{2.5}(\leq 2.5 \mu \mathrm{m}), \mathrm{PM}_{1}(\leq 1 \mu \mathrm{m})$ and $\mathrm{PM}_{0.1}$ $(\leq 0.1 \mu \mathrm{m}) . \mathrm{PM}_{10}$ are also called "thoracic" particles since they can penetrate into the lower respiratory system; PM2.5, or "respirable" particles, as ultra fine particles are more dangerous since they are more abundant and with a higher lung penetration potential. There is scientific evidence of the increase in respiratory and cardiovascular diseases and mortality linked with inhalation of particulates (Brunekreef and Holgate, 2002).

\section{Climate change}

In parallel with growing awareness about the stratospheric ozone depletion and the transboundary gas pollution, during the eighties the theory of anthropogenic global warming started to be suggested and some international initiatives were established within UNEP.

In 1988 UNEP in conjunction with the World Meteorological Organization (WMO) created the International Panel on Climate Change (IPCC) and subsequently conceived the United Nation Framework Convention on Climate Change (UNFCCC) in 1992 (UN, 1992). The UNFCCC concerns all the greenhouse gases not covered by the Montreal Protocol and parties accept to compile periodical inventories of their national emissions and produce national communications reporting the actions to implement the Convention (such as mitigation measures, research, promotion of public awareness, etc.). Under UNFCCC, in 1997 was adopted the Kyoto Protocol (UNFCCC, 1977), setting legally binding emission targets for industrialized countries. The Kyoto Protocol focuses on the following substances: $\mathrm{CO}_{2}, \mathrm{CH}_{4}, \mathrm{~N}_{2} \mathrm{O}$, HFCs, PFCs and $\mathrm{SF}_{6}$.
Generally, parties must reduce their emissions with respect to a standard reference (or base year) that is 1990 for the 38 signatory developed countries plus the European Union as a whole; the countries with economies in transition (EIT) can choose another base year from 1990 to 1995 , while developing countries have not any quantitative target. Developed countries must reduce their emissions of at least $5.2 \%$ with respect to 1990 in the period 20082012. The pre-2004 15 EU Member States are covered by the "EU burden-sharing" agreement which sets differentiated emission limitations for each state ensuring the overall $8 \%$ emission reduction commitment from the base-year to the 2008-2012 period.

The protocol sets three mechanisms in order to promote the cost-effectiveness of the mitigation actions. These mechanisms are: the Clean Development Mechanism, allowing developed countries to realize environmentally friendly projects in developing countries; the Joint Implementation, allowing developed or EIT countries to implement projects that reduce emissions or increase removals in other developed or EIT countries; the Emission Trading, allowing a developed or EIT country to acquire emission credits from another developed or EIT country that already has achieved its target. If parties do not succeed in achieving their emission target, they must reach their target plus a penalty of 30 per cent within the second commitment period.

At present 172 states have signed and ratified the Kyoto Protocol and in the list is included the European Union as a party. As signatories of UNFCCC, also parties which did not ratify the Kyoto Protocol, such as Australia and United States, annually provide national greenhouse gas inventories following the instructions set by IPCC (IPCC, 2006). Data from IPCC about the so-called "Annex I Parties" (41 developed or EIT parties) show an average reduction of emissions of $-10.6 \%$ in the period 1990-2005. Total greenhouse gas emissions in 2004 were 5\% below 1990 level (EEA, 2006).

Over the $20^{\text {th }}$ Century, the temperature of Earth surface has increased on average by about $0.74 \pm 0.18^{\circ} \mathrm{C}$ (IPCC, 2007), phenomenon commonly known as "global warming". Although a certain number of people and organizations 
Table 3. Contribution of the different GHGs to the greenhouse effect and their IPCC radiative forcing.

\begin{tabular}{lcc}
\hline Gas & $\begin{array}{c}\text { Contribution } \\
\text { to the greenhouse } \\
\text { effect }(\%)^{\mathrm{a}}\end{array}$ & $\begin{array}{c}\text { IPCC radiative } \\
\text { forcing } \\
\left(\mathrm{W} \mathrm{m}^{-2}\right)^{\mathrm{b}}\end{array}$ \\
\hline $\mathrm{CO}_{2}$ & 26 & +1.66 \\
$\mathrm{CH}_{4}$ & 3 & +0.48 \\
Tropospheric $\mathrm{O}_{3}$ & 8 & +0.35 \\
ODSs & $<1$ & +0.32 \\
$\mathrm{~N}_{2} \mathrm{O}$ & 3 & +0.16 \\
Water vapour & 60 & +0.07 \\
HFCs+PFCs+SF & $<1$ & +0.02 \\
Stratospheric $\mathrm{O}_{3}$ & $<1$ & -0.05 \\
Aerosols & $<1$ & -0.50
\end{tabular}

a Source: Kiehl and Trenberth, 1997. b Source: IPCC, 2007. For water vapour only: Hansen et al., 2005.

have expressed their scepticism, the scientific consensus about the current climate change and its anthropogenic origin is basically full, without any substantial disagreement (Crowley, 2000; Hansen et al., 2005; Ll, 2007; Oreskes, 2004).

The rise of the temperature has been related to the increased concentration of some gaseous substances in the atmosphere, identified as "greenhouse gases". There is indeed scientific evidence of their responsibility in intercepting the infrared radiation reflected by the Earth surface and its consequent partial re-emission in the atmosphere. The ultimate result is that a part of the infrared photons can not directly escape to the space and the adsorption/re-emission leads to increase the atmospheric temperatures, stressing the so-called "greenhouse effect".

The greenhouse effect is defined as the difference between the energy emitted by the Earth surface to the atmosphere and that emitted by the upper atmosphere to space (Berger and Tricot, 1992). It is a natural phenomenon essential for the habitability of our planet (Karl and Trenberth, 2003), but the global energy budget has been modified during the last two centuries as a result of the modification in the atmosphere composition caused by human activities. The contribution to the greenhouse effect had been estimated as approximately $60 \%$ for water vapour, $26 \%$ for carbon dioxide $\left(\mathrm{CO}_{2}\right)$, $8 \%$ for tropospheric ozone $\left(\mathrm{O}_{3}\right)$ and $6 \%$ for methane $\left(\mathrm{CH}_{4}\right)$ and nitrous oxide $\left(\mathrm{N}_{2} \mathrm{O}\right)$, in absence of clouds (Kiehl and Trenberth, 1997).

The aggravation of the greenhouse effect has been numerically described through the introduction of the concept of radiative forcing (RF) by the IPCC. In climatology, RF is defined as the difference between the incoming radiation energy and the outgoing radiation in a given climate system. The term was adopted by the IPCC to designate an external imposed perturbation in the radiative energy budget of the Earth's climate system, which may lead to variations in the climate parameters. The IPCC defines RF as "the net change in net irradiance at the tropopause after allowing for stratospheric temperatures to readjust to radiative equilibrium" (Ramaswamy et al., 2001), where the net irradiance is given by the difference between the incoming radiation energy and the outgoing radiation energy.

The contributions to the climatologic radiative forcing (or the properly called greenhouse effect) and to the IPCC radiative forcing (or the aggravation of the greenhouse effect) of different substances are summarized in Table 3.

The theory of the greenhouse effect aggravation caused by the anthropogenic action, claimed for the first time by the Swedish scientist Arrhenius at the end of XIX century (Arrhenius, 1896), began to get stronger during 1980's (Maslin, 2004; Schneider et al., 1980), generating lively debates, especially about uncertainties in climate data sets and models. High-accuracy methods for gas concentration measurements started at the end of 1950's for $\mathrm{CO}_{2}$ (Keeling et al., 1979) and during 1970's for $\mathrm{CH}_{4}$ (Blake et al., 1982) and $\mathrm{N}_{2} \mathrm{O}$ (Weiss, 1981), but the analysis of air enclosed in the ice cores of Antarctica and Greenland revealed an exponential rise of $\mathrm{CO}_{2}, \mathrm{CH}_{4}$ and $\mathrm{N}_{2} \mathrm{O}$ air abundance during the industrial age (Neftel et al., 1985).

Carbon dioxide. Following data from the air enclosed in the ice cores of Antarctica, the preindustrial $\mathrm{CO}_{2}$ atmospheric concentration was in the range of 275-284 ppm (Etheridge et al., 1996), while in 2005 it was approximately 379 ppm. Half of the 100-ppm increase was reached in about 200 years of industrialization (from mid 1700 to 1970s) while the remaining half was achieved in approximately 30 years. High precision measurements of $\mathrm{CO}_{2}$ are currently carried out at several sites in both hemispheres: the first site is that of Mauna Loa (Hawaii), started in 
1958, later supported by Baring Head (New Zealand), Niwot Ridge (Colorado), Cape Grim (Australia), Cape Matatula (American Samoa), Ragged Point (Barbados), Mace Head (Ireland), Trinidad Head (California) and others, under the WMO Global Atmosphere Watch (GAW) programme.

While the main natural source of $\mathrm{CO}_{2}$ is the autotrophic and heterotrophic respiration, the anthropogenic $\mathrm{CO}_{2}$ emissions arise from several different sources, mainly from the fossil fuels combustion (for power generation, transports, industrial processes, residential and commercial buildings), from the conversion of land from forested to agricultural land, during certain industrial processes such as the cement manufacture or the hydrogen production, and following the combustion of biomass. The emitted $\mathrm{CO}_{2}$ can be more or less efficiently absorbed (or "sequestered") by different natural "sinks". The main $\mathrm{C}$ sinks are oceans, plants, soils, sediments, rocks and fossil fuels. Carbon dioxide readily dissolves in water and the oceans provide a reservoir of carbon. There is a continual cycle and equilibration of dissolved $\mathrm{CO}_{2}$ in water with $\mathrm{CO}_{2}$ in the atmosphere. Nevertheless oceans seem not to be an unlimited $\mathrm{CO}_{2}$ sink and globally only a small fraction is found to dissolve deeper than $1500 \mathrm{~m}$ (Sabine et al., 2004). C subtracted by the plants from the atmosphere represents the net balance between the photosynthesis and respiration processes and consists in the live vegetation biomass. The majority of carbon stored in global vegetation is in forests (Goodale et al., 2002). Soil $\mathrm{C}$ sequestration transfers atmospheric $\mathrm{CO}_{2}$ into the stable organic matter pools and it is achieved through the adoption of adequate management practices (Lal, 2004). Limestone contained in marine sediments and in land and aquatic rocks represents a sink of carbon, so as fossil fuels, the latter by now almost exhausted.

Besides the general impact of the climate change, $\mathrm{CO}_{2}$ increase has some specific ecological consequences. The increased dissolution of $\mathrm{CO}_{2}$ in the oceans as carbonic acid induces water acidification and therefore potentially reduces the skeleton formation of some key marine organisms, such as corals and planktons (Feely et al., 2004; Orr et al., 2005). Furthermore, under increased $\mathrm{CO}_{2}$ levels, stomatal apertures on plant leaves are observed to par- tially close, reducing evapotranspiration (Field et al., 1995) and therefore potentially increasing runoff (Gedney et al., 2006). Plants generally increase their productivity under elevated $\mathrm{CO}_{2}$ conditions (Thompson et al., 2005), nevertheless $\mathrm{CO}_{2}$ enrichment seems to enhance soil microbial respiration, potentially limiting $\mathrm{C}$ storage in soils (Heath et al., 2005).

Methane. The methane concentration in atmosphere varied between 350 and $650 \mathrm{ppb}$ (depending on the glacial and interglacial periods) over the last 160000 years, and in the immediate pre-industrial period (1750) was approximately $715 \mathrm{ppb}$, following findings from the Vostok ice core analysis in East Antarctica (Chappellaz et al., 1990). Current high-precision measurements are performed by a network of more than 40 monitoring sites, controlled by NOAA/ESRL (U.S. National Oceanic and Atmospheric Administration/ Earth System Research Laboratory) and AGAGE (Advanced Global Atmospheric Gases Experiment). In 2005, the global average concentration of $\mathrm{CH}_{4}$ was approximately $1.78 \mathrm{ppm}$. While in the last 25 years of high-precision monitoring its concentration rose by approximately $30 \%$, since the end of 1990s this increase was nearly null and the causes of this stabilisation are still largely unclear. Furthermore, there are uncertainties about the origin of the rapid increase over recent centuries, since some human $\mathrm{CH}_{4}$-producing activities, such as biomass burning and rice cultivation, were already widespread in pre-industrial times (Ferretti et al., 2005).

Natural sources of $\mathrm{CH}_{4}$ are microbial methanogenesis due to organic $\mathrm{C}$ mineralization under anaerobic conditions in waterlogged soils (wetlands) (Whalen, 2005), the decomposition of methane hydrates normally present in marine sediments and in polar regions (Bhatnagar et al., 2007), the termites metabolism (Sanderson, 1996), and terrestrial plants (Keppler et al., 2006). $\mathrm{CH}_{4}$ is emitted also by a number of human activities, such as rice cultivation, ruminants livestock farming, waste landfills, manures, biomass burning, fossil fuels extractions, transportation and combustion (Stern and Kaufmann, 1996). The largest sink for $\mathrm{CH}_{4}$ is the troposphere, where it reacts with hydroxyl radicals $\left(\mathrm{OH}^{-}\right)$forming water and $\mathrm{CO}_{2}$ (Lelieveld et al., 1998). Another important methane sink is rep- 
resented by methanotroph bacteria, widespread in aerobic soils and sediments, which use $\mathrm{CH}_{4}$ as a source of carbon (Mancinelli, 1995).

Tropospheric ozone. Tropospheric $\mathrm{O}_{3}$ interacts with both short wave and long-wave radiation and chemically influences $\mathrm{CH}_{4}$ and HCFCs, therefore affecting directly and indirectly the atmosphere radiative budget.

Nitrous oxide. $\mathrm{N}_{2} \mathrm{O}$ ice core analyses revealed a mixing ratio relatively stable over the 1800 years before industrialization (approximately $270 \mathrm{ppb}$ ) and a rapid rise after 1750 (Meure et al., 2006), producing a global average concentration of $319 \mathrm{ppb}$ in 2005. High-precision measurements are at present performed at several sites, under the NOAA/ESRL GMD, AGAGE and WMO GAW programmes.

Natural $\mathrm{N}_{2} \mathrm{O}$ sources are tropical and temperate soils and oceans (Hirsch et al., 2006), through the microbial processes of nitrification and denitrification. The dominant anthropogenic $\mathrm{N}_{2} \mathrm{O}$ sources are agricultural soils and biomass burning while industry and combustion are minor contributors (Rockmann et al., 2003). The main sink of $\mathrm{N}_{2} \mathrm{O}$ is stratosphere, where it is photochemically destroyed. This is the reason why $\mathrm{N}_{2} \mathrm{O}$ is the major source of stratospheric $\mathrm{O}_{3}$-depleting $\mathrm{NO}_{\mathrm{x}}$.

Ozone depleting substances. ODSs and a number of their substitutes (i.e. hydrochlorofluorocarbons, and perfluorocarbons) are other recognized greenhouse gases, not naturally present in the ancient air and introduced in atmosphere by human activities (Velders et al., 2007). They are monitored by NOAA/ESRL GMD, AGAGE and WMO GAW networks. Among Montreal Protocol gases, the most relevant contribution to global warming is given by chlorofluorocarbons (CFCs). The use of CFCs has been largely phased out under the Montreal Protocol, but their presence in atmosphere is still high because of their long lifetime. In addition, hydrofluorocarbons (HFCs), perfluorocarbons (PFCs) and sulphur hexafloride $\left(\mathrm{SF}_{6}\right)$, used as Montreal gases substitutes for refrigeration and other uses, albeit benign to stratospheric $\mathrm{O}_{3}$, are greenhouse gases (Shine and Sturges, 2007).

Hydroxyl radical. $\mathrm{OH}^{-}$is the major oxidation agent in the atmosphere and determines the self-cleansing capacity of the troposphere. It is formed in the atmosphere by the reaction of excited atomic oxygen with water. Its high reactivity leads to destroy $\mathrm{CH}_{4}$, HCFCs and HFCs and therefore contributes to determine the total anthropogenic radiative forcing (Ehhalt, 1999). Its formation is dependent on the solar UV radiation and the water vapour concentration and it is therefore controlled by the stratospheric $\mathrm{O}_{3}$ layer thickness (Naik et al., 2005).

Water vapour. From the high precision measurements performed at Boulder (Colorado) since 1980, there is evidence of increasing stratospheric water vapour concentration (Oltmans et al., 2000). The causes of this increase are largely unclear, but it is acknowledged that $\mathrm{CH}_{4}$ increased concentration is partially responsible of this, since the photo oxidation of $\mathrm{CH}_{4}$ is the primary source of water vapour in the stratosphere (Rohs et al., 2006).

Stratospheric ozone. One of the consequences of the stratospheric $\mathrm{O}_{3}$ layer depletion is the change of the tropospheric energy balance, absorbing both the incoming short-wave solar radiation and the Earth's long-wave radiation emitted.

Aerosols. The atmospheric aerosols, that are airborne solid particles or liquid droplets, are responsible of scattering and absorption of incoming short-wave and long-wave emitted radiation (Bellouin et al., 2005). They also affect composition, amount and lifetime of clouds (Lohmann and Feichter, 2005; Novakov and Penner, 1993). The anthropogenic aerosols have a heterogeneous composition, including: sulphate aerosols, composed by sulphuric acid partly or totally neutralized by ammonia; nitrate aerosols, formed by reaction of nitric acid with ammonia after sulphuric acid is totally neutralized; organic aerosols, composed by several different carbon compounds and produced by the fossil fuel and biofuel combustion; black carbon, that is a form of carbon produced by the incomplete combustion of fossil fuel, wood, and biomass; mineral dust aerosols, mainly produced during soil disturbance following agricultural practices and during cement production and transport (Andreae, 2007; Kalberer et al., 2004; Schaap et al., 2002; Schaap et al., 2004). The radiative forcing of the singular aerosol classes can be very different, being negative for the ma- 
jority of them and positive for black carbon; IPCC produced a combination of these different values, reported in Table 3 .

\section{The role of the agriculture in the climate change}

The evaluation of the impact of agriculture on the state of the climate is extremely composite, involves manifold aspects and therefore requires an integrated approach.

Data from UNFCCC Secretariat estimate a total contribution of agriculture of $10-12 \%$ (5.16.1 $\mathrm{Pg} \mathrm{CO} 2$ eq per year) of the total greenhouse gases (GHGs) anthropogenic emissions in 2005 (Verchot, 2007). This sector accounts for $59-63 \%$ global non- $\mathrm{CO}_{2}$ GHGs emissions: in detail 84\% of globally emitted $\mathrm{N}_{2} \mathrm{O}$ and $54 \%$ of $\mathrm{CH}_{4}$ (EPA, 2006). Energy related $\mathrm{CO}_{2}$ emissions (including emissions from manufacture of fertilizer) from agriculture are comparatively low (0.6 $\mathrm{Pg} \mathrm{CO}_{2}$ eq), but the consumption of fossil fuels considerably increases when food industry and related transport are considered. Furthermore, it is opportune to take into account as contribution of the agriculture sector also the emissions following the conversion from natural grassland and forest to croplands or pasturelands: land use change is currently associated to an estimated emissions value of 7.6 $\mathrm{Pg} \mathrm{CO}_{2}$ eq per year.

Agricultural activities mainly act on the atmosphere composition and the climate change through three sets of processes:

i) the land use change,

ii) the emission of GHGs, and

iii) the GHGs mitigation (Seguin et al., 2007).

\subsection{Land-use change}

The change of the land-use due to agriculture activities affects the climate both modifying the soil-atmosphere fluxes of heat and moisture and emitting $\mathrm{CO}_{2}$.

Agriculture has an impact upon the local and global climate through the transformation and management of the vegetation. The vegetation itself and its impact on land cover influence the transfer of heat and moisture from the land surface to the air, in relation to leaf area, stomatal resistance, root depth, albedo and surface roughness (Raddatz, 2007). Agriculture activities leaded to a vast change in the global land use, thus altering the vegetation distribution and therefore the climate. For example, deforestation reduces net radiation and precipitation and increases surface temperatures while irrigation has opposite effects (Franchito and Rao, 1992).

Expansion of cultivated land is currently limited to some tropical humid regions, but in the past three centuries the area of cultivated land increased on average by $600 \%$ and currently the best estimate obtained from census data and satellite images states that croplands and pasturelands cover $12 \%$ and $22 \%$ of the Earth's land surface, respectively (Raddatz, 2007). It is estimated that man-made changes in land-use have, until now, produced a cumulative global loss of $\mathrm{C}$ from the land of about $170 \mathrm{Pg}$. Losses primarily occur due to the reduction of the relatively long-term plant and soil carbon sinks of natural grassland forests being replaced by agricultural land (Sauerbeck, 2001).

\subsection{Direct nitrous oxide emissions}

Anthropogenic $\mathrm{N}_{2} \mathrm{O}$ emissions are largely biogenic (i.e. microbiologically mediated) and the contribution of abiogenic processes, such as biomass burning, is negligible. For example, data from UNFCCC Secretariat for European Union (27) in 2005 show that the large majority of $\mathrm{N}_{2} \mathrm{O}$ was emitted from agricultural soils $(88.0 \%)$ and manure management $(11.8 \%)$.

Biogenic production of $\mathrm{N}_{2} \mathrm{O}$ in soil is mainly attributed to two microbiological processes: nitrification and denitrification (Bateman and Baggs, 2005; Granli and Bockman, 1994 and references therein). Nitrification is an aerobic process carried out by both autotrophic and heterotrophic microorganisms. The two-steps autotrophic nitrification is partly performed by the ammonium oxidizers (responsible of the transformation from $\mathrm{NH}_{4}^{+}$to nitrite and identified by Nitroso- prefix) and partly by the nitrite oxidizers (responsible of nitrite to nitrate oxidation and designated by Nitro-prefix). $\mathrm{N}_{2} \mathrm{O}$ is a by-product of nitrification but it still unclear the mechanism of its production (Khalil et al., 2004). It is however acknowledged that one of the processes involved is nitrifier denitrification, i.e. the use of nitrite $\left(\mathrm{NO}_{2}^{-}\right)$as an alternative electron acceptor by ammonia oxidizers under $\mathrm{O}_{2}$ limiting conditions thus producing $\mathrm{N}_{2} \mathrm{O}$ (Wrage et al., 2001). Under certain conditions of low $\mathrm{pH}$ and high organic compounds avail- 
ability (coniferous forests), a number of heterotrophic microorganisms, mainly fungi, can oxidise $\mathrm{NH}_{4}^{+}$or organic $\mathrm{N}$ compounds to obtain energy. The importance of heterotrophic nitrification in $\mathrm{N}_{2} \mathrm{O}$ production, although not fully investigated, is rather limited (Pedersen et al., 1999). Denitrification can be performed both by heterotrophs and autotrophs. The most widespread process is heterotrophic denitrification, where microorganisms (both bacteria and fungi) use $\mathrm{NO}_{3}^{-}$or $\mathrm{NO}_{2}^{-}$as primary electron acceptor under anaerobic conditions. Denitrifying bacteria follow different reduction pathways, leading to the production of only $\mathrm{N}_{2} \mathrm{O}$, only $\mathrm{N}_{2}$ or a mixture of them, depending on the species but also on the environmental conditions (Hofstra and Bouwman, 2005). Autotrophic denitrification only occurs in very limited conditions (e.g. in zones rich in FeS) when specific microorganisms obtain energy from $\mathrm{NO}_{3}^{-}$for the oxidation of inorganic compounds, such as $\mathrm{S}^{2-}$ and $\mathrm{Fe}^{2+}$ (Manconi et al., 2007). A minor abiogenic $\mathrm{N}_{2} \mathrm{O}$-producing process is chemodenitrification that is the chemical decomposition of $\mathrm{NO}_{2}^{-}$following the reaction with some organic and inorganic compounds.

The major regulators of nitrification and denitrification are soil texture and $\mathrm{pH}$, temperature, soil aeration, water content, quantity and quality of organic $\mathrm{C}$ and nitrogen availability. Soil aeration depends on water content, diffusion of $\mathrm{O}_{2}$ into the soil and consumption of $\mathrm{O}_{2}$ by soil microorganisms and plant roots. Agricultural activities can therefore affect it mainly trough irrigation, tillage and availability of organic substrates. Several studies demonstrated that $\mathrm{N}_{2} \mathrm{O}$ emissions are largest when in the soil both aerobic and anaerobic micro sites are abundant, while anoxic conditions favour $\mathrm{N}_{2}$ production. Soil water content, which can be directly controlled by human activities such as the irrigation or the drainage, strongly affects microbial populations, being limiting for their activity and affecting $\mathrm{O}_{2}$ and nutrients availability. As most of soil organisms, nitrifiers and denitrifyiers obtain their energy and substance from organic materials, which directly regulate their activity. Moreover, an indirect effect of organic materials availability is given by enhanced microbial activity promoting $\mathrm{O}_{2}$ consumption and therefore favouring the presence of anoxic mi- cro sites. The presence of organic materials can be regulated by agricultural practices such as manuring, return of crop residue and vegetal covering (Arcara et al., 1999; Baggs et al., 2000; Lopez-Fernandez et al., 2007). The presence of growing plants implies the production of root exudates thus stimulating microbial activity. The impact of crops and vegetation on nitrification and denitrification is also related to root $\mathrm{O}_{2}$ consumption, $\mathrm{N}$ mineral uptake, water use, soil porosity and structure affected by roots, reduced diurnal temperature fluctuation.

The availability of inorganic $\mathrm{N}$ forms, such as $\mathrm{NH}_{4}^{+}$and $\mathrm{NO}_{3}^{-}$, are regulated in the soil by soil organic matter mineralization, atmospheric deposition, nitrogen fixation and plant uptake. Agricultural practices can strongly affect the $\mathrm{N}$ availability, primarily through fertilization. Following the estimates provided by IFA (International Fertilizer industry Association), the global use of $\mathrm{N}$ is approximately 200 millions of $\mathrm{t}$ per year and this data is expected to further increase in the future to sustain food production. Furthermore farmers use large quantities of animal manure to fertilize crop and grassland. The $\mathrm{N}$ supplied through fertilizers and manures is not efficiently used by plants therefore resulting in losses to the environment through leaching, volatilisation and gaseous losses. Farmers have several opportunities to limit $\mathrm{N}_{2} \mathrm{O}$ emissions adopting appropriate practices regarding type and amount of fertilizer applied, method and time of application, composition of manure. Most techniques proposed to match $\mathrm{N}$ supply and demand are found to be effective to limit $\mathrm{N}_{2} \mathrm{O}$ emissions, e.g. the use of the proper form and amount of $\mathrm{N}$ fertilizer according to soil and crop type and climatic conditions (Clayton et al., 1997), the addition of nitrification inhibitors (Abbasi and Adams, 2000; McTaggart and Tsuruta, 2003), the choice of tillage moment and crop rotation (Wagner-Riddle and Thurtell, 1998), the modification of manure composition both through animal diet and manure processing (Amon et al., 2006; Velthof et al., 2005).

The agricultural activity contributes to overall $\mathrm{N}_{2} \mathrm{O}$ emissions also through the manure storing. The emission of $\mathrm{N}_{2} \mathrm{O}$ during the storage depends on the nitrogen and carbon content of manure, on the duration of the storage and on 
the type of manure treatment (Amon et al., 2006). The composition of manure can be modified through the animal diet, in order to improve productivity and at the same time reduce $\mathrm{N}$ content of urine and faeces (Oenema et al., 2001; Reijs et al., 2007; van Vliet et al., 2007) or through several type of processing, such as aeration (Loyon et al., 2007), addition of straw (Thorman et al., 2007), solid-liquid separation (Hansen et al., 2006) or digestion (Sommer et al., 2000).

\subsection{Direct methane emissions}

The primary contribution of livestock to $\mathrm{CH}_{4}$ emissions is through the enteric fermentation, that is the digestion process performed by microorganisms present in the stomachs of herbivores, leading to simple molecules production from complex carbohydrates; $\mathrm{CH}_{4}$ is a by-product of this process. The strategies for reducing $\mathrm{CH}_{4}$ losses from enteric fermentation include improving rumen fermentation efficiency using inhibitors of the methanogenesis or feed additives, introducing in the diet high digestibility feeds and modifying rumen microflora (Sirohi et al., 2007).

Livestock manure gives a significant contribution to global $\mathrm{CH}_{4}$ emissions, technically surmountable or better exploitable for energy production. The anaerobic digestion of manure can in fact lead to the production of biogas utilizable as substitute of fossil fuel contemporaneously reducing $\mathrm{CH}_{4}$ emissions (Moller et al., 2004).

Rice fields have a high potential to produce $\mathrm{CH}_{4}$. Methanogen bacteria are strict anaerobes and require highly reducing conditions, as occurring in flooded rice fields. Mitigation options include water management (mid-season drainage), addition of oxidant substances such as sulphates and nitrates, minimizing the incorporation of organic amendments (e.g. rice straw), choosing the right rice variety (with low $\mathrm{C}$ root exudates and an high harvest index and having a low aerenchymatic $\mathrm{CH}_{4}$ transport) (Yagi, 2006).

\subsection{GHGs mitigation}

In addition to reducing emissions from specific activities, the agricultural sector offers other opportunities for the climate change mitigation. In fact agriculture is expected to contribute to the atmospheric $\mathrm{CO}_{2}$ concentration stabilisation through the substitution of fossil fuels by biofuels and the sequestration of $\mathrm{C}$ in soil and vegetal biomass.

The vegetal biomass can be used directly for energy production (solid combustion of wood and residue of crops, e.g. sugar cane or maize), and indirectly for the production of liquid fuels such as bioethanol or biodiesel, or for biogas production (Demirbas, 2005). C released during the combustion of vegetal biomass is potentially balanced by $\mathrm{C}$ reabsorbed by new plant growth. However the net effect on the overall greenhouse effect is still in discussion since the cultivation of biomass for energy production implies the use of $\mathrm{N}$ fertilizer, enhancing $\mathrm{N}_{2} \mathrm{O}$ emissions (Crutzen et al., 2007). Furthermore the extent of the fossil fuel- $\mathrm{CO}_{2}$ saving is not defined yet given that the energy balance of the biomass cultivation is currently under evaluation (Farrell et al., 2006). The terrestrial C sinks that can be enriched to contrast atmospheric $\mathrm{CO}_{2}$ increase are principally living vegetal biomass and soil organic matter (Lal, 2008).

Forestation, reforestation and agroforestry are possible way to sequester $\mathrm{C}$ from atmosphere to plant biomass (Montagnini and Nair, 2004; Sedjo, 1993).

Since land use change from forest and natural grassland to cropland has depleted soil $\mathrm{C}$ content over past millennia, agricultural soils at present represent a potential $\mathrm{CO}_{2}$ sink (Paustian et al., 1997). It is subsequently obvious that the potential to sequester $\mathrm{C}$ by soils is not unlimited and native soil $\mathrm{C}$ content represents the ideal maximum attainable $\mathrm{C}$ level (Paustian et al., 2000). There are several management practices to adopt in order to enhance soil $\mathrm{C}$ content, such as reducing or eliminating soil tillage, enhancing crop residue return, using animal manures, conversion to more intensive cropping systems (Freibauer et al., 2004; Halvorson et al., 2002; West and Marland, 2002).

Provided that the increase of the soil C stock undoubtedly has several positive externalities for agricultural systems besides $\mathrm{C}$ sequestration, the effectiveness of transferring atmospheric $\mathrm{CO}_{2}$ to terrestrial stocks is still debated. The main ambiguity is linked to the timescale of $\mathrm{C}$ sequestration. Fossil fuel emis- 
sions, constituting the main $\mathrm{CO}_{2}$ pool to contrast, are basically irreversible, whereas plant and soil $\mathrm{C}$ are vulnerable to return to the atmosphere in the course of decades or centuries. This is the main reason why many scientists refuse the idea implied in the Clean Development Mechanism of the Kyoto Protocol, that enlarging terrestrial $\mathrm{C}$ sink is equivalent to reduce fossil fuel consumption (Ingram and Fernandes, 2001; Sauerbeck, 2001).

\section{References}

Abbasi M.K., Adams W.A. 2000. Estimation of simultaneous nitrification and denitrification in grassland soil associated with urea-N using $\mathrm{N}-15$ and nitrification inhibitor. Biol. Fert. Soils, 31:38-44.

Ahmed O.H., Aminuddin H., Husni M.H.A. 2006. Reducing ammonia loss from urea and improving soilexchangeable ammonium retention through mixing triple superphosphate, humic acid and zeolite. Soil Use Manage., 22:315-319.

Amon B., Kryvoruchko V., Amon T., ZechmeisterBoltenstern S. 2006. Methane, nitrous oxide and ammonia emissions during storage and after application of dairy cattle slurry and influence of slurry treatment. Agr. Ecosyst. Environ., 112:153-162.

Andreae M.O. 2007. Aerosols before pollution. Science, 315:50-51.

Arcara P.G., Gamba C., Bidini D., Marchetti R. 1999. The effect of urea and pig slurry fertilization on denitrification, direct nitrous oxide emission, volatile fatty acids, water-soluble carbon and anthrone-reactive carbon in maize-cropped soil from the Po plain (Modena, Italy). Biol. Fert. Soils, 29:270-276.

Arrhenius S. 1896. On the Influence of Carbonic Acid in the Air Upon the Temperature of the Ground. Philos. Mag., 41:237-276.

Asman W.A.H., Vanjaarsveld H.A. 1992. A Variable-Resolution Transport Model Applied for NHx in Europe. Atmos. Environ. Part A, 26:445-464.

Baath E. 1989. Effects of Heavy-Metals in Soil on Microbial Processes and Populations (a Review). Water Air Soil Poll., 47:335-379.

Baggs E.M., Rees R.M., Smith K.A., Vinten A.J.A. 2000. Nitrous oxide emission from soils after incorporating crop residues. Soil Use Manage., 16:82-87.

Balsari P., Airoldi G., Dinuccio E., Gioelli F. 2007. Ammonia emissions from farmyard manure heaps and slurry stores - Effect of environmental conditions and measuring methods. Biosyst. Eng., 97:456-463.

Bateman E.J., Baggs E.M. 2005. Contributions of nitrification and denitrification to $\mathrm{N}_{2} \mathrm{O}$ emissions from soils at different water-filled pore space. Biol. Fert. Soils, 41:379-388.
Bates D.R., Nicolet M. 1950. Atmospheric hydrogen. Publ. Astron. Soc. Pac., 62:106-110.

Bellouin N., Boucher O., Haywood J., Reddy M.S. 2005. Global estimate of aerosol direct radiative forcing from satellite measurements. Nature, 438:1138-1141.

Berger A., Tricot C. 1992. The Greenhouse-Effect. Surv. Geophys., 13:523-549.

Bhatnagar G., Chapman W.G., Dickens G.R., Dugan B., Hirasaki G.J. 2007. Generalization of gas hydrate distribution and saturation in marine sediments by scaling of thermodynamic and transport processes. Am. J. Sci., 307:861-900.

Blake D.R., Mayer E.W., Tyler T.C., Makide Y., Montague D.C., Rowland F.S. 1982. Global Increase in Atmospheric Methane Concentrations between 1978 and 1980. Geophys. Res. Lett., 9:477-480.

Boeglin M.L., Wessels D., Henshel D. 2006. An investigation of the relationship between air emissions of volatile organic compounds and the incidence of cancer in Indiana counties. Environ. Res., 100:242-254.

Brunekreef B., Holgate S.T. 2002. Air pollution and health. Lancet, 360:1233-1242.

Bussink D.W., Oenema O. 1998. Ammonia volatilization from dairy farming systems in temperate areas: a review. Nutr. Cycling Agroecosyst., 51:19-33.

Byrnes B.H. 1990. Environmental-Effects of N Fertilizer Use - an Overview. Fert. Res., 26:209-215.

Chan A.S.K., Steudler P.A. 2006. Carbon monoxide uptake kinetics in unamended and long-term nitrogenamended temperate forest soils. FEMS Microbiol. Ecol., 57:343-354.

Chantigny M.H., Rochette P., Angers D.A., Masse D., Cote D. 2004. Ammonia volatilization and selected soil characteristics following application of anaerobically digested pig slurry. Soil Sci. Soc. Am. J., 68:306-312.

Chapman S. 1930. On ozone and atomic oxygen in the upper atmosphere. Philos. Mag., 10:369-383.

Chappellaz J., Barnola J.M., Raynaud D., Lorius C., Korotkevich Y.S. 1990. Ice-core record of atmospheric methane over the past 160,000 years. Nature, 345:127-131.

Chen T.M., Gokhale J., Shofer S., Kuschner W.G. 2007. Outdoor air pollution: Nitrogen dioxide, sulfur dioxide, and carbon monoxide health effects. Am. J. Med. Sci., 333:249-256.

Clayton H., McTaggart I.P., Parker J., Swan L., Smith K.A. 1997. Nitrous oxide emissions from fertilised grassland: A 2-year study of the effects of $\mathrm{N}$ fertiliser form and environmental conditions. Biol. Fert. Soils, 25:252-260.

CLRTAP 1979. Geneva Convention on Long-range Transboundary Air Pollution, Geneva (SW).

Crowley T.J. 2000. Causes of climate change over the past 1000 years. Science, 289:270-277.

Crutzen P.J. 1970. The influence of nitrogen oxides on the atmospheric ozone content. Q. J. R. Meteorolog. Soc., 96:320-325. 
Crutzen P.J., Mosier A.R., Smith K.A., Winiwarter W. 2007. $\mathrm{N}_{2} \mathrm{O}$ release from agro-biofuel production negates global warming reduction by replacing fossil fuels. Atmos. Chem. Phys., 7:11191-11202.

de Gruijl F.R., Longstreth J., Norval M., Cullen A.P., Slaper H., Kripke M.L., Takizawa Y., van der Leun J.C. 2003. Health effects from stratospheric ozone depletion and interactions with climate change. Photoch. Photobio. Sci., 2:16-28.

Demirbas A. 2005. Potential applications of renewable energy sources, biomass combustion problems in boiler power systems and combustion related environmental issues. Prog. Energ. Comb., 31:171-192.

EEA 2006. Greenhouse gas emission trends and projections in Europe 2006, Copenaghen (DK).

EEA 2007. Annual European Community LRTAP Convention Emission Inventory report 1990-2005.

Ehhalt D.H. 1999. Gas phase chemistry of the troposphere. In: Baumgaertel H. et al. (eds.): Global aspects of atmospheric chemistry, 21-110. Springer Verlag, Darmstadt, Germany.

EMEP 2004. EMEP Assessment Part I European Perspective, Oslo, Norway.

EPA 2006. Global anthropogenic non- $\mathrm{CO}_{2}$ greenhouse gas emissions: 1990-2020, Washington, USA.

EPA 2007. Achievements in stratospheric ozone protection - Progress report, Washington, USA.

EEC 1970. Council Directive 70/220/EEC of 20 March 1970 on the approximation of the laws of the Member States relating to measures to be taken against air pollution by gases from positive-ignition engines of motor vehicles.

EEC 1992. Council Directive 92/43/EEC of 21 May 1992 on the conservation of natural habitats and of wild fauna and flora.

EC 1994. European Parliament and Council Directive 94/63/EC of 20 December 1994 on the control of volatile organic compound (VOC) emissions resulting from the storage of petrol and its distribution from terminals to service stations.

EC 1996a. Council Directive 96/62/EC of 27 September 1996 on ambient air quality assessment and management.

EC 1996b. Council Directive 96/61/EC of 24 September 1996 concerning integrated pollution prevention and control.

EC 1998. Directive 98/70/EC of the European Parliament and of the Council of 13 October 1998 relating to the quality of petrol and diesel fuels and amending Council Directive 93/12/EEC.

EC 1999a. Council Directive 1999/13/EC of 11 March 1999 on the limitation of emissions of volatile organic compounds due to the use of organic solvents in certain activities and installations.

EC 1999b. Council Directive 1999/30/EC of 22 April 1999 relating to limit values for sulphur dioxide, ni- trogen dioxide and oxides of nitrogen, particulate matter and lead in ambient air.

EC 1999c. Council Directive 1999/32/EC of 26 April 1999 relating to a reduction in the sulphur content of certain liquid fuels and amending Directive 93/12/EEC.

EC 2000a. Directive 2000/76/EC of the European Parliament and of the Council of 4 December 2000 on the incineration of waste.

EC 2000b. Directive 2000/69/EC of the European Parliament and of the Council of 16 November 2000 relating to limit values for benzene and carbon monoxide in ambient air.

EC 2000c. Regulation (EC) No 2037/2000 of the European Parliament and of the Council of 29 June 2000 on substances that deplete the ozone layer.

EC 2001a. Directive 2001/81/EC of the European Parliament and of the Council of 23 October 2001 on national emission ceilings for certain atmospheric pollutants.

EC 2001b. Directive 2001/80/EC of the European Parliament and of the Council of 23 October 2001 on the limitation of emissions of certain pollutants into the air from large combustion plants.

EC 2002. Directive 2002/3/EC of the European Parliament and of the Council of 12 February 2002 relating to ozone in ambient air.

EC 2004a. Directive 2004/42/CE of the European Parliament and of the Council of 21 April 2004 on the limitation of emissions of volatile organic compounds due to the use of organic solvents in certain paints and varnishes and vehicle refinishing products and amending Directive 1999/13/EC.

EC 2004b. Directive 2004/107/EC of the European Parliament and of the Council of 15 December 2004 relating to arsenic, cadmium, mercury, nickel and polycyclic aromatic hydrocarbons in ambient air.

EC 2005. Directive 2005/55/EC of the European Parliament and of the Council of 28 September 2005 on the approximation of the laws of the Member States relating to the measures to be taken against the emission of gaseous and particulate pollutants from compression-ignition engines for use in vehicles, and the emission of gaseous pollutants from positive-ignition engines fuelled with natural gas or liquefied petroleum gas for use in vehicles.

EC 2008. Directive 2008/1/EC of the European Parliament and of the Council of 15 January 2008 concerning integrated pollution prevention and control.

Etheridge D.M., Steele L.P., Langenfelds R.L., Francey R.J., Barnola J.M., Morgan V.I. 1996. Natural and anthropogenic changes in atmospheric $\mathrm{CO}_{2}$ over the last 1000 years from air in Antarctic ice and firn. J. Geophys. Res.-Atmos., 101:4115-4128.

FAO, IFA 2001. Global estimates of gaseous emissions of $\mathrm{NH}_{3}, \mathrm{NO}$ and $\mathrm{N}_{2} \mathrm{O}$ from agricultural land, Rome, Italy. 
Farman J., Gardiner B.G., Shanklin J.D. 1985. Large losses of ozone in Antarctica reveal seasonal ClOx/NOx interaction. Nature. 315:207-210.

Farrell A.E., Plevin R.J., Turner B.T., Jones A.D., O'Hare M., Kammen D.M. 2006. Ethanol can contribute to energy and environmental goals. Science, 311:506-508.

Feely R.A., Sabine C.L., Lee K., Berelson W., Kleypas J., Fabry V.J., Millero F.J. 2004. Impact of anthropogenic $\mathrm{CO}_{2}$ on the $\mathrm{CaCO}_{3}$ system in the oceans. Science, 305:362-366.

Fenn L.B., Kissel D.E. 1976. The influence of cation exchange capacity and depth of incorporation on ammonia volatilization from ammonium compounds applied to calcareous soils. Soil Sci. Soc. Am. J., 40:394-398.

Fenn M.E., Poth M.A., Aber J.D., Baron J.S., Bormann B.T., Johnson D.W., Lemly A.D., McNulty S.G., Ryan D.E., Stottlemyer R. 1998. Nitrogen excess in North American ecosystems: Predisposing factors, ecosystem responses, and management strategies. Ecol. Appl., 8:706-733.

Fenn M.E., Baron J.S., Allen E.B., Rueth H.M., Nydick K.R., Geiser L., Bowman W.D., Sickman J.O., Meixner T., Johnson D.W., Neitlich P. 2003. Ecological effects of nitrogen deposition in the western United States. Bioscience, 53:404-420.

Ferretti D.F., Miller J.B., White J.W.C., Etheridge D.M., Lassey K.R., Lowe D.C., Meure C.M.M., Dreier M.F., Trudinger C.M., van Ommen T.D., Langenfelds R.L. 2005. Unexpected changes to the global methane budget over the past 2000 years. Science, 309:1714-1717.

Field C.B., Jackson R.B., Mooney H.A. 1995. Stomatal Responses to Increased $\mathrm{CO}_{2}$ - Implications from the Plant to the Global-Scale. Plant, Cell Environ., 18:1214-1225.

Franchito S.H., Rao V.B. 1992. Climatic-Change Due to Land Surface Alterations. Clim. Change, 22:1-34.

Freibauer A., Rounsevell M.D.A., Smith P., Verhagen J. 2004. Carbon sequestration in the agricultural soils of Europe. Geoderma, 122:1-23.

Fuhrer J., Skarby L., Ashmore M.R. 1997. Critical levels for ozone effects on vegetation in Europe. Environ. Pollut., 97:91-106.

Galloway J.N., Likens G.E. 1981. Acid precipitation: the importance of nitric acid. Atmos. Environ., 15:10811085.

Garrido F., Henault C., Gaillard H., Perez S., Germon J.C. 2002. $\mathrm{N}_{2} \mathrm{O}$ and $\mathrm{NO}$ emissions by agricultural soils with low hydraulic potentials. Soil Biol. Biochem., 34:559-575.

Gauss M., Myhre G., Isaksen I.S.A., Grewe V., Pitari G., Wild O., Collins W.J., Dentener F.J., Ellingsen K., Gohar L.K., Hauglustaine D.A., Iachetti D., Lamarque J.F., Mancini E., Mickley L.J., Prather M.J., Pyle J.A., Sanderson M.G., Shine K.P., Stevenson D.S., Sudo K., Szopa S., Zeng G. 2006. Radiative forcing since preindustrial times due to ozone change in the troposphere and the lower stratosphere. Atmos. Chem. Phys., 6:575-599.
Gedney N., Cox P.M., Betts R.A., Boucher O., Huntingford C., Stott P.A. 2006. Detection of a direct carbon dioxide effect in continental river runoff records. Nature, 439:835-838.

Goodale C.L., Apps M.J., Birdsey R.A., Field C.B., Heath L.S., Houghton R.A., Jenkins J.C., Kohlmaier G.H., Kurz W., Liu S.R., Nabuurs G.J., Nilsson S., Shvidenko A.Z. 2002. Forest carbon sinks in the Northern Hemisphere. Ecol. Appl., 12:891-899.

Granli T., Bøckman O.C. 1994. Nitrous oxide from agriculture. Norweg. J. Agr. Sci., Suppl. 12:128.

Halvorson A.D., Wienhold B.J., Black A.L. 2002. Tillage, nitrogen, and cropping system effects on soil carbon sequestration. Soil Sci. Soc. Am. J., 66:906-912.

Hansen J., Nazarenko L., Ruedy R., Sato M., Willis J., Del Genio A., Koch D., Lacis A., Lo K., Menon S., Novakov T., Perlwitz J., Russell G., Schmidt G.A., Tausnev N. 2005. Earth's energy imbalance: Confirmation and implications. Science, 308:1431-1435.

Hansen M.N., Henriksen K., Sommer S.G. 2006. Observations of production and emission of greenhouse gases and ammonia during storage of solids separated from pig slurry: Effects of covering. Atmos. Environ., 40:4172-4181.

Heath J., Ayres E., Possell M., Bardgett R.B., Black H.I.J., Grant H., Ineson P., Kerstiens G. 2005. Rising atmospheric $\mathrm{CO}_{2}$ reduces sequestration of root-derived soil carbon. Science, 309:1711-1713.

Hendrey G.R., Wright R.F. 1975. Acid precipitation in Norway: effects on aquatic fauna. In: Elder F., Matheson D. (eds.): First specialty symposium on atmospheric contributions to the chemistry of lake waters. International Association Great Lakes Research, Orilia, Ontario.

Hirsch A.I., Michalak A.M., Bruhwiler L.M., Peters W., Dlugokencky E.J., Tans P.P. 2006. Inverse modeling estimates of the global nitrous oxide surface flux from 1998-2001. Global Biogeochem. Cycles, 20.

Hobbs P.J., Webb J., Mottram T.T., Grant B., Misselbrook T.M. 2004. Emissions of volatile organic compounds originating from UK livestock agriculture. J. Sci. Food Agric., 84:1414-1420.

Hofstra N., Bouwman A.F. 2005. Denitrification in agricultural soils: Summarizing published data and estimating global annual rates. Nutr. Cycling Agroecosyst., 72:267-278.

Hopfner M., Luo B.P., Massoli P., Cairo F., Spang R., Snels M., Di Donfrancesco G., Stiller G., von Clarmann T., Fischer H., Biermann U. 2006. Spectroscopic evidence for NAT, STS, and ice in MIPAS infrared limb emission measurements of polar stratospheric clouds. Atmos. Chem. Phys., 6:1201-1219.

Ingram J.S.I., Fernandes E.C.M. 2001. Managing carbon sequestration in soils: concepts and terminology. Agric. Ecosyst. Environ., 87:111-117.

IPCC 2006. 2006 IPCC Guidelines for National Greenhouse Gas Inventories IGES, Hayama. 
IPCC 2007. Climate change 2007. The physical science basis Cambridge University Press.

Jarup L. 2003. Hazards of heavy metal contamination. Br. Med. Bull., 68:167-182.

Kabir Z., Fennimore S.A., Duniway J.M., Martin F.N., Browne G.T., Winterbottom C.Q., Ajwa H.A., Westerdahl B.B., Goodhue R.E., Haar M.J. 2005. Alternatives to methyl bromide for strawberry runner plant production. Hortscience, 40:1709-1715.

Kalberer M., Paulsen D., Sax M., Steinbacher M., Dommen J., Prevot A.S.H., Fisseha R., Weingartner E., Frankevich V., Zenobi R., Baltensperger U. 2004. Identification of polymers as major components of atmospheric organic aerosols. Science, 303:1659-1662.

Karentz D., Bosch I. 2001. Influence of ozone-related increases in ultraviolet radiation on antarctic marine organisms. Am. Zool., 41:3-16.

Karl T.R., Trenberth K.E. 2003. Modern global climate change. Science, 302:1719-1723.

Keeling C.D., Mook W.G., Tans P.P. 1979. Recent trends in the ${ }^{13} \mathrm{C} /{ }^{12} \mathrm{C}$ ratio of atmospheric carbon dioxide. Nature, 277:121-122.

Keppler F., Hamilton J.T.G., Brass M., Rockmann T. 2006. Methane emissions from terrestrial plants under aerobic conditions. Nature, 439:187-191.

Khalil K., Mary B., Renault P. 2004. Nitrous oxide production by nitrification and denitrification in soil aggregates as affected by $\mathrm{O}_{2}$ concentration. Soil Biol. Biochem., 36:687-699.

Kiehl J.T., Trenberth K.E. 1997. Earth's annual global mean energy budget. Bull. Am. Meteorol. Soc., 78:197-208.

Lal R. 2004. Soil carbon sequestration impacts on global climate change and food security. Science, 304:1623-1627.

Lal R. 2008. Soils and sustainable agriculture. A review. Agron. Sustainable Dev., 28:57-64.

Le Cadre E., Genermont S., Decuq C., Recous S., Cellier P. 2005. A laboratory system to estimate ammonia volatilization. Agron. Sustainable Dev., 25:101-107.

Lelieveld J., Crutzen P.J., Dentener F.J. 1998. Changing concentration, lifetime and climate forcing of atmospheric methane. Tellus B, 50:128-150.

Li Q.Q., Loganath A., Chong Y.S., Tan J., Obbard J.P. 2006. Persistent organic pollutants and adverse health effects in humans. J. Toxicol. Environ. Health-Part A, 69:1987-2005.

Liu G.D., Li Y.C., Alva A.K. 2007. Temperature quotients of ammonia emission of different nitrogen sources applied to four agricultural soils. Soil Sci. Soc. Am. J., 71:1482-1489.

Ll C.S. 2007. Quantifying greenhouse gas emissions from soils: Scientific basis and modeling approach. Soil Sci. Plant Nutr., 53:344-352.

Lohmann U., Feichter J. 2005. Global indirect aerosol effects: a review. Atmos. Chem. Phys., 5:715-737.
Lopez-Fernandez S., Diez J.A., Hernaiz P., Arce A., Garcia-Torres L., Vallejo A. 2007. Effects of fertiliser type and the presence or absence of plants on nitrous oxide emissions from irrigated soils. Nutr. Cycling Agroecosyst., 78:279-289.

Loyon L., Guiziou F., Beline E., Peu P. 2007. Gaseous Emissions $\left(\mathrm{NH}_{3}, \mathrm{~N}_{2} \mathrm{O}, \mathrm{CH}_{4}\right.$ and $\left.\mathrm{CO}_{2}\right)$ from the aerobic treatment of piggery slurry - Comparison with a conventional storage system. Biosystems Eng., 97:472-480.

Mancinelli R.L. 1995. The Regulation of Methane Oxidation in Soil. Annu. Rev. Microbiol., 49:581-605.

Manconi I., Carucci A., Lens P. 2007. Combined removal of sulfur compounds and nitrate by autotrophic denitrification in bioaugmented activated sludge system. Biotechnol. Bioeng., 98:551-560.

Maslin M. 2004. Global warming: a very short introduction Oxford University Press.

McTaggart I.P., Tsuruta H. 2003. The influence of controlled release fertilisers and the form of applied fertiliser nitrogen on nitrous oxide emissions from an andosol. Nutr. Cycling Agroecosyst., 67:47-54.

Meijide A., Diez J.A., Sanchez-Martin L., Lopez-Fernandez S., Vallejo A. 2007. Nitrogen oxide emissions from an irrigated maize crop amended with treated pig slurries and composts in a Mediterranean climate. Agric. Ecosyst. Environ., 121:383-394.

Meure Mac Farling C., Etheridge D., Trudinger C., Steele P., Langenfelds R., van Ommen T., Smith A., Elkins J. 2006. Law Dome $\mathrm{CO}_{2}, \mathrm{CH}_{4}$ and $\mathrm{N}_{2} \mathrm{O}$ ice core records extended to 2000 years BP. Geophys. Res. Lett., 33 .

Meyers T.P., Luke W.T., Meisinger J.J. 2006. Fluxes of ammonia and sulfate over maize using relaxed eddy accumulation. Agric. For. Meteorol., 136:203-213.

Molina M.J., Rowland F.S. 1974. Stratospheric sink for chlorofluoromethanes: chlorine atom-catalysed destruction of ozone. Nature, 249:810-812.

Moller H.B., Sommer S.G., Ahring B. 2004. Methane productivity of manure, straw and solid fractions of manure. Biomass Bioenergy, 26:485-495.

Montagnini F., Nair P.K.R. 2004. Carbon sequestration: An underexploited environmental benefit of agroforestry systems. Agroforest. Syst., 61:281-295.

Moxley J.M., Smith K.A. 1998. Factors affecting utilisation of atmospheric CO by soils. Soil Biol. Biochem., 30:65-79.

Myhre G., Stordal F., Berglen T.F., Sundet J.K., Isaksen I.S.A. 2004. Uncertainties in the radiative forcing due to sulfate aerosols. J. Atmos. Sci., 61:485-498.

Naik V., Mauzerall D., Horowitz L., Schwarzkopf M.D., Ramaswamy V., Oppenheimer M. 2005. Net radiative forcing due to changes in regional emissions of tropospheric ozone precursors. J. Geophys. Res.-Atmos., 110.

Neftel A., Moor H., Oeschger H., Stauffer B. 1985. Evidence from polar ice cores for the increase in atmospheric $\mathrm{CO}_{2}$ in the past two centuries. Nature, 315:45-47. 
Novakov T., Penner J.E. 1993. Large Contribution of Organic Aerosols to Cloud-Condensation-Nuclei Concentrations. Nature, 365:823-826.

Novelli P.C., Masarie K.A., Tans P.P., Lang P.M. 1994. Recent Changes in Atmospheric Carbon-Monoxide. Science, 263:1587-1590.

Oden S. 1968. The acidification of air and precipitation and its consequences in the natural environment. In: SNSR Swedish National Science Research Council (ed.): Ecology Committee Bulletin No. 1. Translation Consultants, Ltd. Arlington, Stockholm, 117.

Oenema O., Velthof G., Kuikman P. 2001. Technical and policy aspects of strategies to decrease greenhouse gas emissions from agriculture. Nutr. Cycling Agroecosyst., 60:301-315.

Oltmans S.J., Vomel H., Hofmann D.J., Rosenlof K.H., Kley D. 2000. The increase in stratospheric water vapor from balloonborne, frostpoint hygrometer measurements at Washington, DC, and Boulder, Colorado. Geophys. Res. Lett., 27:3453-3456.

Oreskes N. 2004. Beyond the ivory tower - The scientific consensus on climate change. Science, 306:1686-1686.

Orr J.C., Fabry V.J., Aumont O., Bopp L., Doney S.C., Feely R.A., Gnanadesikan A., Gruber N., Ishida A., Joos F., Key R.M., Lindsay K., Maier-Reimer E., Matear R., Monfray P., Mouchet A., Najjar R.G., Plattner G.K., Rodgers K.B., Sabine C.L., Sarmiento J.L., Schlitzer R., Slater R.D., Totterdell I.J., Weirig M.F., Yamanaka Y., Yool A. 2005. Anthropogenic ocean acidification over the twenty-first century and its impact on calcifying organisms. Nature, 437:681-686.

Paustian K., Six J., Elliott E.T., Hunt H.W. 2000. Management options for reducing $\mathrm{CO} 2$ emissions from agricultural soils. Biogeochemistry, 48:147-163.

Paustian K., Andren O., Janzen H.H., Lal R., Smith P., Tian G., Tiessen H., Van Noordwijk M., Woomer P.L. 1997. Agricultural soils as a sink to mitigate $\mathrm{CO}_{2}$ emissions. Soil Use Manage., 13:230-244.

Pedersen H., Dunkin K.A., Firestone M.K. 1999. The relative importance of autotrophic and heterotrophic nitrification in a conifer forest soil as measured by $\mathrm{N}$ 15 tracer and pool dilution techniques. Biogeochemistry, 44:135-150.

Pinto M., Merino P., del Prado A., Estavillo J.M., Yamulki S., Gebauer G., Piertzak S., Lauf J., Oenema O. 2004. Increased emissions of nitric oxide and nitrous oxide following tillage of a perennial pasture. Nutr. Cycling Agroecosyst., 70:13-22.

Raddatz R.L. 2007. Evidence for the influence of agriculture on weather and climate through the transformation and management of vegetation: Illustrated by examples from the Canadian Prairies. Agric. For. Meteorol., 142:186-202.

Ramaswamy V., Boucher, Ghan S., Smith S.J. 2001. Radiative Forcing of Climate Change. In: Houghton J.T. (ed.): Climate Change 2001: The Scientific Basis, 351416, Cambridge University Press, Cambridge, UK.
Reijs J.W., Sonneveld M.P.W., Sorensen P., Schils R.L.M., Groot J.C.J., Lantinga E.A. 2007. Effects of different diets on utilization of nitrogen from cattle slurry applied to grassland on a sandy soil in The Netherlands. Agric. Ecosyst. Environ., 118:65-79.

Ritter L., Solomon K.R., Forget J., Stemeroff M., O'Leary C. 2007. Persistent organic pollutants: an assessment report on ddt-aldrin-dieldrin-endrin-chlordane-heptachlor-hexachlorobenzene-mirextoxaphene-polychlorinated biphenyls-dioxins and furans. Prepared for The International Programme on Chemical Safety (IPCS), within the framework of the Inter-Organization Programme for the Sound Management of Chemicals (IOMC).

Rockmann T., Kaiser J., Brenninkmeijer C.A.M. 2003. The isotopic fingerprint of the pre-industrial and the anthropogenic $\mathrm{N}_{2} \mathrm{O}$ source. Atmos. Chem. Phys., 3:315-323.

Rohs S., Schiller C., Riese M., Engel A., Schmidt U., Wetter T., Levin I., Nakazawa T., Aoki S. 2006. Long-term changes of methane and hydrogen in the stratosphere in the period 1978-2003 and their impact on the abundance of stratospheric water vapor. J. Geophys. Res.Atmos., 111.

Rugutt J.K., Ngigi A.N., Rugutt K.J., Ndalut P.K. 2006. Native Kenyan plants as possible alternatives to methyl bromide in soil fumigation. Phytomedicine, 13:576-583.

Sabine C.L., Feely R.A., Gruber N., Key R.M., Lee K., Bullister J.L., Wanninkhof R., Wong C.S., Wallace D.W.R., Tilbrook B., Millero F.J., Peng T.H., Kozyr A., Ono T., Rios A.F. 2004. The oceanic sink for anthropogenic $\mathrm{CO}_{2}$. Science, 305:367-371.

Sanderson M.G. 1996. Biomass of termites and their emissions of methane and carbon dioxide: A global database. Global Biogeochem. Cycles 10:543-557.

Sauerbeck D.R. 2001. $\mathrm{CO}_{2}$ emissions and C sequestration by agriculture - perspectives and limitations. $\mathrm{Nu}-$ tr. Cycling Agroecosyst., 60:253-266.

Schaap M., Muller K., ten Brink H.M. 2002. Constructing the European aerosol nitrate concentration field from quality analysed data. Atmos. Environ., 36:13231335.

Schaap M., Van Der Gon H.A.C.D., Dentener F.J., Visschedijk A.J.H., Van Loon M., ten Brink H.M., Putaud J.P., Guillaume B., Liousse C., Builtjes P.J.H. 2004. Anthropogenic black carbon and fine aerosol distribution over Europe. J. Geophys. Res.-Atmos., 109.

Schneider S.H., Kellogg W.W., Ramanathan V., Leovy C.B., Idso S.B. 1980. Carbon dioxide and climate (Exchange of Letters). Science, 210:6-8.

Sedjo R.A. 1993. The Carbon-Cycle and Global Forest Ecosystem. Water Air Soil Poll., 70:295-307.

Seguin B., Arrouays D., Balesdent J., Soussana J.F., Bondeau A., Smith P., Zaehle S., de Noblet N., Viovy N. 2007. Moderating the impact of agriculture on climate. Agric. For. Meteorol., 142:278-287. 
Shick J.M., Lesser M.P., Jokiel P.L. 1996. Effects of ultraviolet radiation on corals and other coral reef organisms. Global Change Biol., 2:527-545.

Shine K.P., Sturges W.T. 2007. Atmospheric science $\mathrm{CO}_{2}$ is not the only gas. Science, 315:1804-1805.

Sirohi S., Michaelowa A., Sirohi S.K. 2007. Mitigation options for enteric methane emissions from dairy animals: an evaluation for potential CDM projects in India. Mitig. Adapt. Strat. Global Change, 12:259-274.

Solomon S. 1999. Stratospheric ozone depletion: A review of concepts and history. Rev. Geophys., 37:275-316.

Sommer S.G., Petersen S.O., Sogaard H.T. 2000. Greenhouse gas emission from stored livestock slurry. J. Environ. Qual., 29:744-751.

Staehelin J., Kegel R., Harris N.R.P. 1998. Trend analysis of the homogenized total ozone series of Arosa (Switzerland), 1926-1996. J. Geophys. Res.-Atmos., 103:8389-8399.

Stern D.I., Kaufmann R.K. 1996. Estimates of global anthropogenic methane emissions 1860-1993. Chemosphere, 33:159-176.

Stieb D.M., Burnett R.T., Beveridge R.C., Brook J.R. 1996. Association between ozone and asthma emergency department visits in Saint John, New Brunswick, Canada. Environ. Health Perspect., 104:1354-1360.

Stolarski R.S., Cicerone R.J. 1974. Stratospheric chlorine: a possible sink for ozone. Can. J. Chem., 52:1610-1615.

Taylor F.W. 2005. Elementary climate physics Oxford University Press.

Thompson A.M., Brown R.A., Rosenberg N.J., Izaurralde R.C., Benson V. 2005. Climate change impacts for the conterminous USA: an integrated assessment. Part 3. Dryland production of grain and forage crops. Clim. Change, 69:43-65.

Thorman R.E., Chadwick D.R., Harrison R., Boyles L.O., Matthews R. 2007. The effect on $\mathrm{N}_{2} \mathrm{O}$ emissions of storage conditions and rapid incorporation of pig and cattle farmyard manure into tillage land. Biosystems Eng., 97:501-511.

UN 1992. United Nations Framework Convention on Climate Change, New York, USA.

UNECE 1979. Convention on long-range transboundary air pollution, Geneva, Italy.

UNECE 1985. Protocol to the 1979 convention on longrange transboundary air pollution on the reduction of sulphur emissions or their transboundary fluxes by at least 30 per cent, Helsinki, Finland.

UNECE 1988. Protocol to the 1979 convention on longrange transboundary air pollution concerning the control of emissions of nitrogen oxides or their transboundary fluxes, Sofia, Turkey.

UNECE 1991. Protocol to the 1979 convention on longrange transboundary air pollution concerning the control of emissions of volatile organic compounds or their transboundary fluxes, Geneva, Italy.
UNECE. 1994. Protocol to the 1979 convention on longrange transboundary air pollution on further reduction of sulphur emissions, Oslo, Norway.

UNECE 1998a. Protocol to the 1979 convention on long-range transboundary air pollution on heavy metals, Aarhaus, Denmark.

UNECE 1998b. Protocol to the 1979 convention on long-range transboundary air pollution on persistent organic pollutants, Aarhaus, Denmark.

UNECE 1999. Protocol to the 1979 convention on longrange transboundary air pollution to abate acidification, eutrophication and ground-level ozone, Gothenburg, Sweden.

UNEP 1987. The Montreal Protocol on substances that deplete the ozone layer.

UNEP 2005. Production and Consumption of Ozone Depleting Substances under the Montreal Protocol 1986 - 2004, Nairobi, Kenya.

UNFCCC 1997. Kyoto Protocol to the United Nations Framework Convention on Climate Change.

Van Breemen N., Burrough P.A., Velthorst E.J., Van Dobben H.F., Wit T.D., Ridder T.B., Reijenders H.F.R. 1982. Soil acidification from atmospheric ammonium sulphate in forest canopy throughfall. Nature, 229:548-550.

van Vliet P.C.J., Reijs J.W., Bloem J., Dijkstra J., de Goede R.G.M. 2007. Effects of cow diet on the microbial community and organic matter and nitrogen content of Feces. J. Dairy Sci., 90:5146-5158.

Velders G.J.M., Andersen S.O., Daniel J.S., Fahey D.W., McFarland M. 2007. The importance of the Montreal Protocol in protecting climate. PNAS, 104:48144819.

Velthof G.L., Nelemans J.A., Oenema O., Kuikman P.I. 2005. Gaseous nitrogen and carbon losses from pig manure derived from different diets. J. Environ. Qual., 34:698-706.

Verchot L.V. 2007. Opportunities for climate change mitigation in agriculture and investment requirements to take advantage of these opportunities. A report to the UNFCCC Secretariat Financial and Technical Support Programme, Nairobi, Kenya.

Vestreng V., Myhre G., Fagerli H., Reis S., Tarrason L. 2007. Twenty-five years of continuous sulphur dioxide emission reduction in Europe. Atmos. Chem. Phys., 7:3663-3681.

Wagner-Riddle C., Thurtell G.W. 1998. Nitrous oxide emissions from agricultural fields during winter and spring thaw as affected by management practices. Nutr. Cycling Agroecosyst., 52:151-163.

Watson C.J., Miller H., Poland P., Kilpatrick D.J., Allen M.D.B., Garrett M.K., Christianson C.B. 1994. Soil Properties and the Ability of the Urease Inhibitor N(N-Butyl) Thiophosphoric Triamide (Nbtpt) to Reduce Ammonia Volatilization from Surface-Applied Urea. Soil Biol. Biochem., 26:1165-1171.

Weiss R.F. 1981. The temporal and spatial distribution 
of tropospheric nitrous oxide. J. Geophys. Res., 86:7185-7195.

West T.O., Marland G. 2002. A synthesis of carbon sequestration, carbon emissions, and net carbon flux in agriculture: comparing tillage practices in the United States. Agric. Ecosyst. Environ., 91:217-232.

Whalen S.C. 2005. Biogeochemistry of methane exchange between natural wetlands and the atmosphere. Environ. Eng. Sci., 22:73-94.

Wrage N., Velthof G.L., van Beusichem M.L., Oenema O.
2001. Role of nitrifier denitrification in the production of nitrous oxide. Soil Biol. Biochem., 33:1723-1732.

Yagi K. 2006. Methane emission in rice, mitigation options for. In: Lal R. (ed.): Encyclopedia of Soil Science. Taylor \& Francis.

Young A.R. 1997. The biological effects of ozone depletion. Br. J. Clin. Pract., Suppl. 89:10-15.

Yung Y.L., Pinto J.P., Watson R.T., Sander S.P. 1980. Atmospheric bromine and ozone perturabations in the lower stratosphere. J. Atmos. Sci., 37:339-353. 